OPEN ACCESS

Edited by:

Alexander Cruden,

Monash University, Australia

Reviewed by:

Harvey Kelsey,

Humboldt State University,

United States

R. Jayangonda Perumal, Wadia Institute of Himalayan Geology,

India

*Correspondence:

Nathan A. Toké

nathan.toke@uvu.edu

Specialty section:

This article was submitted to Structural Geology and Tectonics,

a section of the journal

Frontiers in Earth Science

Received: 16 September 2020 Accepted: 22 February 2021

Published: 15 March 2021

Citation:

Toké NA, Phillips J, Langevin C, Kleber E, DuRoss CB, Hiscock Al, McDonald GN, Wells JD, Carlson JK and Horns DM (2021) The Traverse Ridge Paleoseismic Site and Ruptures

Crossing the Boundary Between

the Provo and Salt Lake City Segments of the Wasatch Fault Zone,

Utah, United States.

Front. Earth Sci. 9:607018. doi: 10.3389/feart.2021.607018

\section{The Traverse Ridge Paleoseismic Site and Ruptures Crossing the Boundary Between the Provo and Salt Lake City Segments of the Wasatch Fault Zone, Utah, United States}

Nathan A. Toké ${ }^{1 *}$, Joseph Phillips ${ }^{1}$, Christopher Langevin ${ }^{1}$, Emily Kleber ${ }^{2}$, Christopher B. DuRoss ${ }^{3}$, Adam I. Hiscock ${ }^{2}$, Greg N. McDonald², Jack D. Wells ${ }^{1}$, J. Kade Carlson ${ }^{1}$ and Daniel M. Horns ${ }^{1}$

\footnotetext{
'Department of Earth Science, Utah Valley University, Orem, UT, United States, ${ }^{2}$ Geologic Hazards Program, Utah Geological Survey, Salt Lake City, UT, United States, ${ }^{3}$ Geologic Hazards Science Center, U.S. Geological Survey, Golden, CO, United States
}

How structural segment boundaries modulate earthquake behavior is an important scientific and societal question, especially for the Wasatch fault zone (WFZ) where urban areas lie along multiple fault segments. The extent to which segment boundaries arrest ruptures, host moderate magnitude earthquakes, or transmit ruptures to adjacent fault segments is critical for understanding seismic hazard. To help address this outstanding issue, we conducted a paleoseismic investigation at the Traverse Ridge paleoseismic site (TR site) along the $\sim 7-\mathrm{km}$-long Fort Canyon segment boundary, which links the Provo $(59 \mathrm{~km})$ and Salt Lake City $(40 \mathrm{~km})$ segments of the WFZ. At the TR site, we logged two trenches which were cut across sub-parallel traces of the fault, separated by $\sim 175$ $\mathrm{m}$. Evidence from these exposures leads us to infer that at least 3 to 4 earthquakes have ruptured across the segment boundary in the Holocene. Radiocarbon dating of soil material developed below and above fault scarp colluvial packages and within a filled fissure constrains the age of the events. The most recent event ruptured the southern fault trace between 0.2 and $0.4 \mathrm{ka}$, the penultimate event ruptured the northern fault trace between 0.6 and $3.4 \mathrm{ka}$, and two prior events occurred between 1.4 and $6.2 \mathrm{ka}$ (on the southern fault trace) and 7.2 and $8.1 \mathrm{ka}$ (northern fault trace). Colluvial wedge heights of these events ranged from 0.7 to $1.2 \mathrm{~m}$, indicating the segment boundary experiences surface ruptures with more than $1 \mathrm{~m}$ of vertical displacement. Given these estimates, we infer that these events were greater than Mw 6.7, with rupture extending across the entire segment boundary and portions of one or both adjacent fault segments. The Holocene recurrence of events at the TR site is lower than the closest paleoseismic sites at the adjacent fault segment endpoints. The contrasts in recurrence rates observed within $15 \mathrm{~km}$ of the Fort Canyon fault segment boundary may be explained conceptually by a leaky segment boundary model which permits spillover events, ruptures centered 
on the segment boundary, and segmented ruptures. The TR site demonstrates the utility of paleoseismology within segment boundaries which, through corroboration of displacement data, can demonstrate rupture connectivity between fault segments and test the validity of rupture models.

Keywords: paleoseismology, wasatch fault, segmentation, earthquake geology, seismic hazard

\section{INTRODUCTION}

The Wasatch fault zone (WFZ: Figure 1) is one of the most well-studied normal faults on Earth. Its earthquake history has been scrutinized since G.K. Gilbert's early reconnaissance work on the Quaternary geology of the Basin and Range region (Gilbert, 1884, 1928). The WFZ was utilized as a primary example for the development of the characteristic earthquake hypothesis (Schwartz and Coppersmith, 1984), and it has been a prime site for developing and testing ideas about the role of segmentation (i.e., defined by changes along-strike fault structural complexities) in earthquake ruptures (e.g., Machette et al., 1991; McCalpin and Nishenko, 1996; DuRoss et al., 2016). Because of the long history of paleoseismic investigation across multiple sites on the central WFZ, the Fort Canyon segment boundary fault (FCSB: a $\sim 7 \mathrm{~km}$-long fault bend across a mountain salient which separates the Salt Lake City and Provo segments of the central WFZ; Figure 1) is an excellent location to examine the importance of segmentation in the modulation of earthquake hazard.

In this paper, we present a paleoseismic investigation of the FCSB and a case study examination of the central WFZ that addresses the issue of how a normal fault structural segment boundary may modulate earthquake rupture. This is an important scientific and societal question to address. Global compilations of empirical data demonstrate that ruptures along normal faults can bridge relatively large steps and gaps in fault traces of up to $8 \mathrm{~km}$ (e.g., Wesnousky, 2008; Biasi and Wesnousky, 2016). Furthermore, the importance of segment boundaries in controlling fault rupture propagation has been relaxed in recent large-scale seismic hazard analyses in California (Field et al., 2014), and relaxing of segmentation has recently been explored along the WFZ (Valentini et al., 2019). Furthermore, notable recent earthquakes along strike-slip and subduction zone environments have ruptured across large along-strike structural complexities (e.g., Taylor et al., 2008), demonstrating that segment boundaries and characteristic earthquakes do not encapsulate earthquake behavior (e.g., Philibosian and Meltzner, 2020). In the case of the FCSB, a multi-segment rupture of the Provo and Salt Lake City segments presents a different, and possibly worse, scenario to overcome for the State of Utah than the rupture of a single fault segment. The population centers adjacent to these two fault segments contain the majority of Utah residents and commercial enterprises (e.g., Wong et al., 2016). Furthermore, how adjacent segments interact is a longstanding question that is related to fault geometry, rupture dynamics, fault maturity, and the state of stress within the system. Documenting the chronologies of prehistoric earthquake ruptures (i.e., paleoseismic records) that are arrested or transmitted between specific fault segments can provide data to test the importance of fault geometry, rupture directivity, and other parameters in controlling fault interaction.

Beyond correlating paleoseismic event chronologies from nearby sites and segments (e.g., Schwartz and Coppersmith, 1984; Machette et al., 1991; Weldon et al., 2004; DuRoss and Hylland, 2015; DuRoss et al., 2016), there are at least three ways to collect data about the role of fault segment boundaries in modulating earthquake rupture. The best data sources for understanding the role of fault segments and gaps in rupture dynamics are the historical record of field-documented large earthquakes (e.g., Sieh, 1978; Crone et al., 1987; Prentice and Schwartz, 1991; Pantosti et al., 1996; Taylor et al., 2008) and compilations of such data that permit the development of empirical relationships (e.g., Wells and Coppersmith, 1994; Stirling et al., 2002; Wesnousky, 2006, 2008; Manighetti et al., 2007; Stirling et al., 2013; Biasi and Wesnousky, 2016). However, the instrumental and historical records of well-documented events are limited to those events that have occurred during the last several hundred years and only a few well-documented case studies exist for normal faults (e.g., Biasi and Wesnousky, 2016). Another approach has been the utilization of high-resolution topography to map displacement gradients for historical and pre-historic events (e.g., Zielke et al., 2010, 2012; Haddon et al., 2016; DuRoss et al., 2019; Sare et al., 2019). Finally, one approach is to document paleoseismic histories directly within segment boundaries (e.g., Seitz et al., 1997; Toké et al., 2011; Wang et al., 2017). These types of records provide direct evidence of ruptures at a segment boundary that can then be compared to paleoseismic records on adjacent fault segments.

Previous investigations along the central WFZ include eight paleoseismic sites along the Salt Lake City (4) and Provo (4) segments. The Salt Lake City segment sites include the Penrose Drive site (DuRoss et al., 2014; DuRoss and Hylland, 2015), the Little Cottonwood Canyon site (Swan et al., 1980; McCalpin, 2002), the South Fork Dry Canyon site (Schwartz and Lund, 1988; Black et al., 1996), and the Corner Canyon site (DuRoss et al., 2018). The Provo segment sites include the Alpine site (Bennett et al., 2018), the American Fork site (Forman et al., 1989), the Rock Canyon site (Lund and Black, 1998), and the Mapleton North/South sites (Olig et al., 2011). Two of the most recent paleoseismic investigations on the WFZ were purposefully situated at the very northern end of the $59 \mathrm{~km}$-long Provo segment (the Alpine Site: Bennett et al., 2018) and the very southern end of the Salt Lake City segment (Corner Canyon Site: DuRoss et al., 2018). These studies collected high-resolution event chronologies and displacement data immediately adjacent to the $\sim 7$-km-long FCSB fault that strikes east - west and links the north - south striking Provo and Salt Lake City segments of 


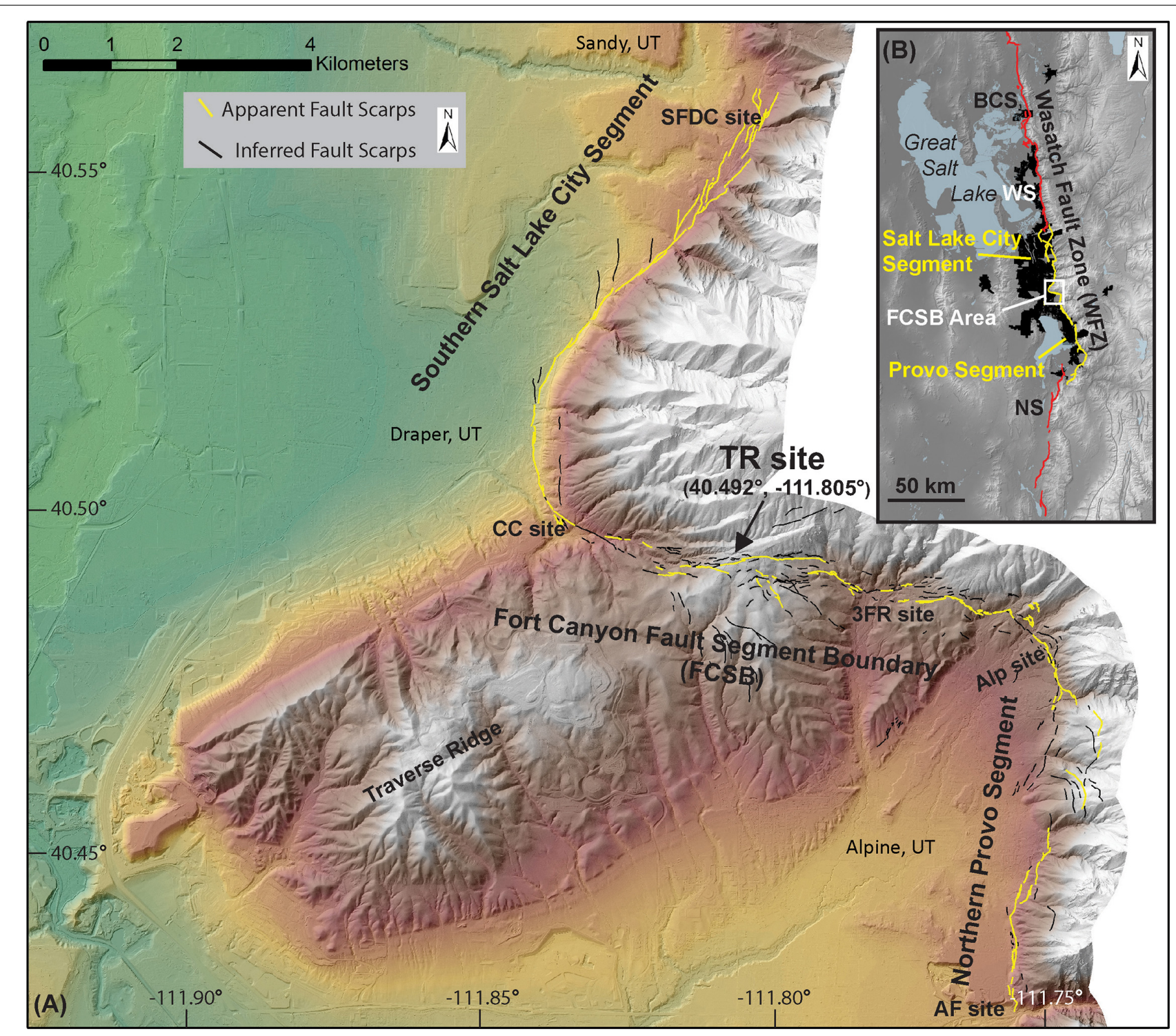

FIGURE 1 | (A) The Fort Canyon segment boundary (FCSB) is the fault linking the Salt Lake City and Provo segments of the Wasatch fault zone (WFZ). Within the segment boundary the fault trace (yellow and black lines) is more complex than the adjacent fault segments (Toké et al., 2017). The Traverse Ridge site (TR site: this paleoseismic study) is located at the crest of Traverse Ridge, midway along the FCSB. Adjacent paleoseismic sites include the South Fork Dry Creek site (SFDC site: Schwartz and Lund, 1988; Black et al., 1996), the Corner Canyon site (CC site: DuRoss et al., 2018), the Three Falls Ranch site (3FR site: Western GeoLogic, 2004), the Alpine site (Alp site: Bennett et al., 2018), and the American Fork site (AF site: Forman et al., 1989). (B) The WFZ extends for more than $300 \mathrm{~km}$ along the urban areas of the Wasatch Front (black regions). This study focuses on the Salt Lake City and Provo fault segments (yellow lines) which cut along the eastern edge of the urbanized area, within $10 \mathrm{~km}$ of more than $50 \%$ of Utah's residents. Other segments (red lines) of the central WFZ include the Brigham City segment (BCS), the Weber segment (WS), and the Nephi segment (NS). The FCSB study area (A) is shown with a white box. Waterbodies (blue) and other Quaternary active faults are shown as faint gray lines over a shaded relief base map.

the WFZ forming a large left step across the segment boundary (Figure 1). These investigations provide the data to begin assessing how this segment boundary may have modulated past earthquake ruptures. Results from the Alpine and Corner Canyon sites show that both sites have experienced three events in the past $1.4 \mathrm{ka}$ and a total of six events since the mid Holocene (Bennett et al., 2018; DuRoss et al., 2018). Per-event displacements and age chronologies permit the interpretation that up to five of the events could be correlated across the FCSB. However, even at high-quality and well-studied sites such as these, geochronology results yield paleoseismic event chronologies with uncertainties that typically range from about 100 to more than 1000 years. Thus, a correlation of events crossing a segment boundary is difficult to distinguish from separate ruptures of adjacent fault segments that are spaced closely in time (e.g., Philibosian and Meltzner, 2020).

In this study, we used the approach of paleoseismology within a segment boundary to acquire an earthquake record that can be compared directly with high-resolution paleoseismic records on the neighboring Salt Lake City and Provo segments of the 
central WFZ. We excavated two trenches across sub-parallel traces of the FCSB fault at the Traverse Ridge paleoseismic site (TR site: $40.492^{\circ},-111.805^{\circ}$ ). The TR site is located near the center of this segment boundary, approximately $4 \mathrm{~km}$ from the Alpine site and $3 \mathrm{~km}$ from the Corner Canyon site (Figure 1). In the first section of the paper, we present the methods utilized in our paleoseismic investigation, including a discussion of site selection based upon previous mapping (Toké et al., 2017: Figures 1, 2). Then, we present the trenching results including soil, stratigraphic, and structural interpretation of the two trenches (Figures 3-6) as well as geochronology samples and results (Tables 1, 2). Next, we compare the event chronologies and displacements from the TR site (Figure 7 and Table 3) with the record from nearby paleoseismic sites (Figure 8). This comparison facilitates discussion about the frequency and dynamics of ruptures extending into the FCSB fault from the adjacent Provo and Salt Lake City segments of the WFZ. Finally, we discuss general challenges for site selection and interpretation of paleoseismic records from within segment boundaries owing to their complex faulting along many parallel fault traces. This paper demonstrates that three to four earthquakes have ruptured through the FCSB since the mid Holocene. This outcome supports the validity of including a diversity of rupture scenarios in seismic hazard analyses for the Wasatch Front (e.g., Wong et al., 2016).

\section{MATERIALS AND METHODS}

\section{Site Selection and Mapping}

As a part of a prior study (Toké et al., 2017), we conducted reconnaissance mapping of the Fort Canyon fault utilizing lidar elevation datasets acquired by the State of Utah. The Fort Canyon fault strikes east - west (nearly perpendicular to the neighboring fault segments) and dips to the south. It runs through the high topography of Traverse Ridge which is a mountain front salient that separates Utah and Salt Lake Valleys (Figure 1). Along the FCSB, Toké et al. (2017) found that the fault surface trace is more complex than on the neighboring fault segments. The segment boundary has a higher density $(\sim 10$ scarps-per-kilometer of fault length) of shorter fault scarp lengths $(\sim 140$ meters per individual fault scarp) than the neighboring fault segments which have lower fault scarp density ( $\sim 6$ scarps-per-kilometer of fault length) and a more continuous fault traces $(\sim 270$ meters per individual fault scarp length). There are several likely reasons for the heightened complexity of the FCSB surface trace. First, segment boundaries often are associated with discontinuous surface fault traces through fault structural complexities (e.g., Sibson, 1986; Graymer et al., 2007; Toké, 2011; DuRoss et al., 2016). Second, the FCSB also contains many Quaternary landslide scarps (e.g., Biek, 2005) that could be misidentified as short fault scarps (e.g., Hart et al., 2012). Third, the Fort Canyon fault trends east west, connecting the Provo and Salt Lake City segments that are west dipping and form a left step across the FCSB. This configuration includes broad $\sim 90$-degree fault bends, resulting in a wide array of surface faults at each junction with the neighboring fault segment. Given this geometry, a component of right-lateral oblique slip may also be possible along the FCSB (e.g., Toké et al., 2017).

Within the array of segment boundary faults, we identified the crest of Traverse Ridge as one of the least complex areas (Figure 2). Here, two prominent fault scarps (a north and south trace) are crossed by the westernmost of seven large and unfilled consultant trenches that were excavated in 2005 as a part of a geologic investigation for a nowabandoned residential development. These scarps are not arcuate and are not associated with mapped landslides. We conducted reconnaissance-level hand-dug excavations of the faulted outcrops in these abandoned trenches and identified this area as the Traverse Ridge paleoseismic site (Toké et al., 2017). Observations from the westernmost trench revealed fault-derived colluvial wedge deposits composed of infilled dark soil A-horizon material mixed with footwall clasts, which we inferred to show strong evidence of Holocene earthquake rupture. Because of the promising deposits, the location near the center of the FCSB, and the area's relatively low fault complexity, we determined that the westernmost trench, hereafter referred to as trench 1 (T1: Figure 2), showed the most promise for further paleoseismic investigation within the segment boundary.

\section{Paleoseismic Trenching}

In the summer of 2016, we re-excavated two sections of trench 1 along the north and south traces of the Fort Canyon fault at the TR site (Figures 2-6). The trench across the north trace of the fault (T1N: Figures 3, 4) was re-oriented from the preexisting exposure to be fault-perpendicular. The trench across the south trace of the fault (T1S: Figures 5, 6) required widening. The T1N re-excavation extended for approximately $13 \mathrm{~m}$ and the T1S reexcavation extended for $\sim 15 \mathrm{~m}$. The trenches reached depths ranging from $1.5-3.5 \mathrm{~m}$ below the ground surface.

Paleoseismic logging was conducted on photomosaics of the trench walls in a style similar to that described in Bemis et al. (2014) and Reitman et al. (2015). The re-excavated faces of T1N and T1S were documented with 16-megapixel digital photographs from an Olympus Stylus Tough camera and a Panasonic Lumix DMC-FZ70. Photographs were taken approximately perpendicular to and at various distances from the trench wall (ranging from 0.5 to $4.0 \mathrm{~m}$ ) to construct photomosaics of varying detail. Each photographic set was taken with more than 50\% overlap. Photographs were processed with Agisoft Photoscan to produce point clouds and three-dimensional models of the trench walls. Photomosaic 'textures' were processed and co-registered with the three-dimensional models enabling us to produce and print orthophoto mosaics of the trench walls. We logged the walls using 8.5 " $\mathrm{x} 11$ " prints of these mosaics at $\sim 1: 5$ scale in the field. We mapped lithologic units, soils, faults, animal burrows, clasts, and other trench features such as trench floors, benches, and excavation spoils where they overlay the modern soil A-horizon (because we were reoccupying trenches that had been dug more than a decade earlier and were not previously infilled). Mapping was digitized from field log scans using Esri ArcGIS software. Following the field work, a trench review was conducted on August 31, 2016, with participants from 
A 0 0.25 0.5 1

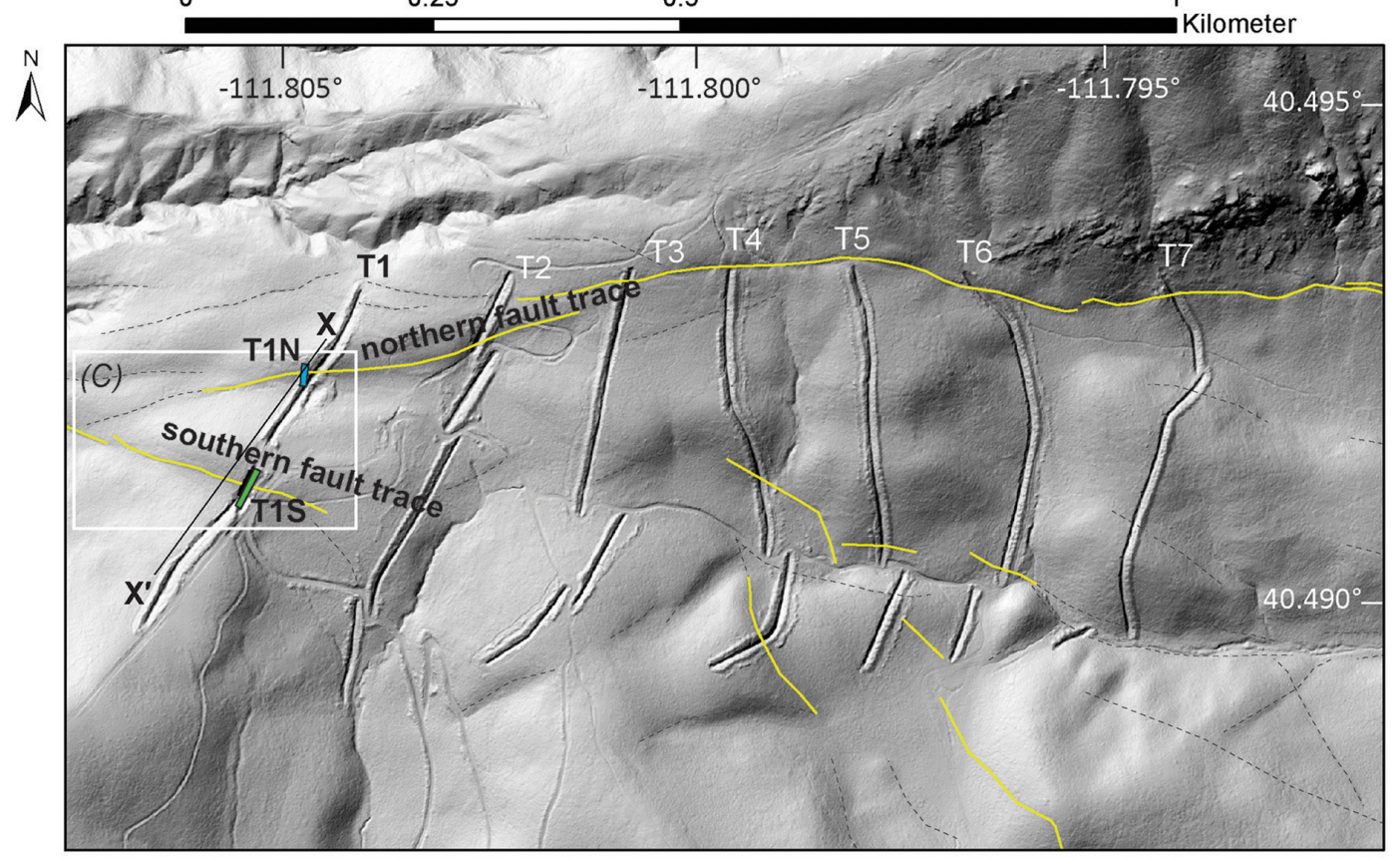

B Cross Sectional Interpretation Facing East

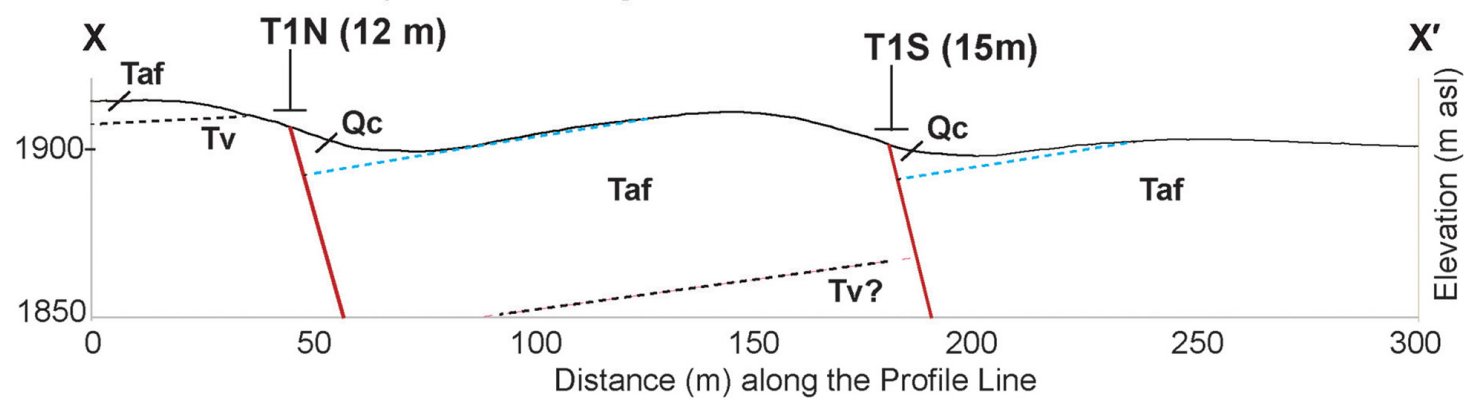

c Fault Intersection between the northern and southern fault traces

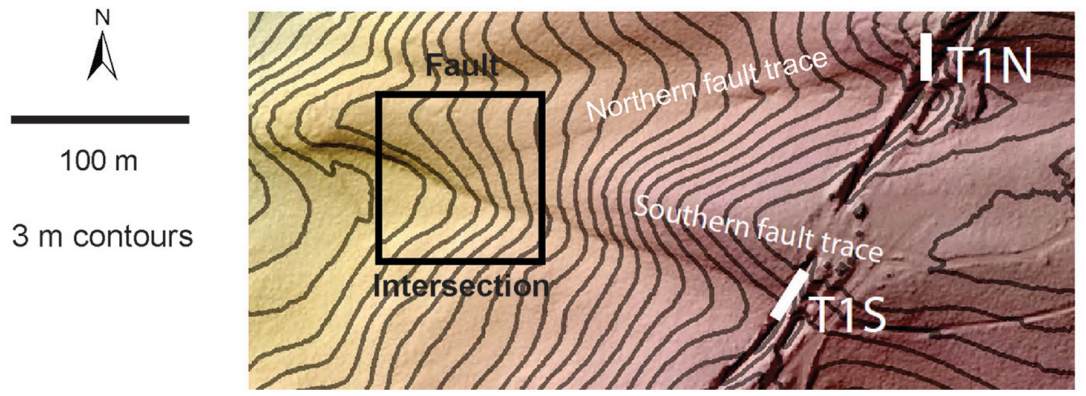

FIGURE 2 | (A) The Traverse Ridge site (TR site) consists of seven 500-m-long paleoseismic trenches (T1-T7) that were originally investigated as part of a geotechnical investigation for a now abandoned housing development. In this study, we reoccupied the westernmost trench (T1). We re-excavated two portions of $\mathrm{T} 1$, which crossed two prominent fault traces. Trench 1 north ( $11 \mathrm{~N}$ : small blue rectangle) was cut across the northern fault trace and reoriented, extending fault-perpendicular for about $14 \mathrm{~m}$ along a $170^{\circ}$ trend from the existing trench at approximately $40.49254^{\circ},-111.80467^{\circ}$. Trench 1 south (T1S: small green rectangle) was exposed along the southern fault trace by widening the existing trench, which was already well oriented, perpendicular to the fault. Base map is a lidar-derived shaded relief map with a $315^{\circ}$ illumination angle. Fault traces (yellow lines) and queried slope discontinuities (dashed black lines) are from Toké et al. (2017). (B) Topographic profile and cross-sectional interpretation from X to $X^{\prime}$. The northern and southern fault scarps cut through Tertiary volcanic (Tv) and alluvial fan (Taf) units (Biek, 2005). Quaternary colluvium (Qc) is observed on the hanging wall of the fault traces. The approximate locations and trench lengths are shown for T1N and T1S. (C) Three-meter contours overlain on a shaded relief map just to the west of the trench site. Here, it appears that the southern fault trace intersects and cuts the northern fault trace (within black box). This observation corresponds to trenching results that demonstrate a younger rupture in the T1S trench (Figures 3-7). 


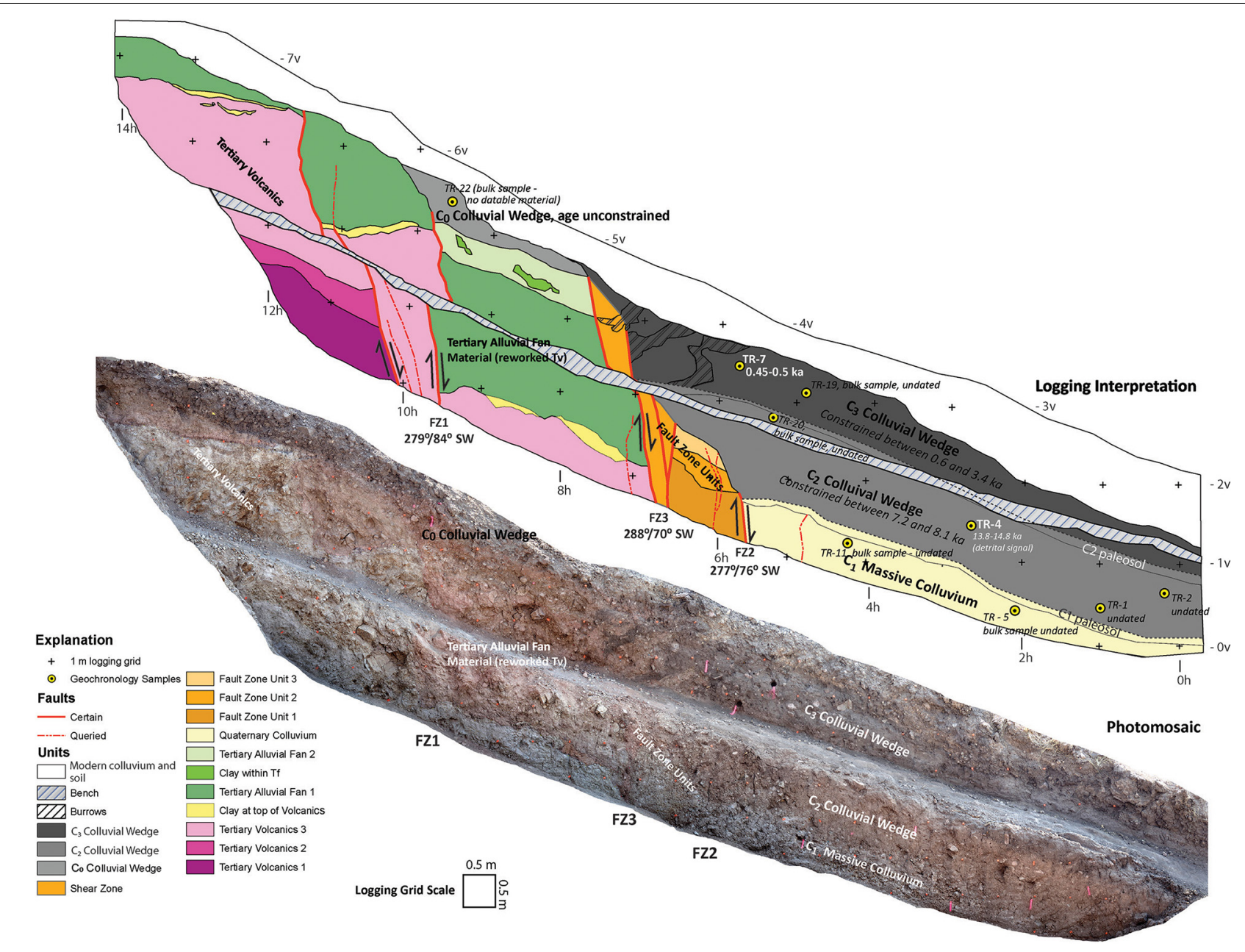

FIGURE 3 | The east wall of Trench One North $(T 1 N)$ presents evidence for three earthquake-produced colluvial wedges $\left(C_{0}, C_{2}\right.$, and $\left.C_{3}\right)$ along three fault zones. Age ranges are constrained for the $C_{2}$ and $C_{3}$ events. Sample TR-7 $(0.3-0.5 \mathrm{ka})$ on this wall is helpful for constraining the age of the event associated with $\mathrm{C}_{3}$

(Figures 7, 8 and Table 1). Other samples constraining these events are found on the west wall (Figure 4 and Table 1). Undated samples and samples that were not included in the event age modeling are shown in italics and smaller font.

the Utah Geological Survey, Utah Valley University, and local geotechnical consultants.

Twenty-eight samples including charred plant material and bulk soil samples were collected for potential radiocarbon analysis (Figures 3-6 and Tables 1, 2). Seventeen radiocarbon samples were analyzed at the Woods Hole Oceanographic Institution National Ocean Sciences Accelerator Mass Spectrometry (NOSAMS) facility in Woods Hole, Massachusetts. Ten of these were preprocessed from six bulk soil samples at PaleoResearch Institute in Golden, Colorado. Radiocarbon ages were calibrated using the IntCal20 model (Reimer et al., 2020) and event ages were modeled following the approach of Lienkaemper and Bronk Ramsey (2009) and Bronk Ramsey (2017) in the program OxCal v. 4.4 (Figures 7, 8 and Tables 1-3). Two optically stimulated luminescence samples were collected, but they were not analyzed because they lacked suitable material (fine sand and silt) for analysis (e.g., Nelson et al., 2015).

\section{RESULTS}

\section{Trench 1 North Stratigraphy and Faulting Events}

The northern trench (T1N: Figures $\mathbf{2 - 4}$ and Table $\mathbf{1}$ ) was situated across a 390-m-long trace of the Fort Canyon fault that trends $260^{\circ}$ and has a southeast facing scarp (Toké et al., 2017). T1N was cut roughly perpendicular to the fault trace extending for $\sim 13 \mathrm{~m}$ along a $\sim 350^{\circ}$ trend from a point at the edge of the preexisting trench footprint (at approximately $40.49254^{\circ}$, $\left.111.80467^{\circ}\right)$. This trench extended to a maximum depth of $\sim 3.5$ $\mathrm{m}$ below the ground surface.

The footwall lithology within T1N is comprised of Tertiary volcanic rock, including a range of deposits from welded block and ash flows to angular alluvium composed of reworked volcanic material (Biek, 2005). Paleosol development was apparent between some of the footwall Tertiary units, and one 


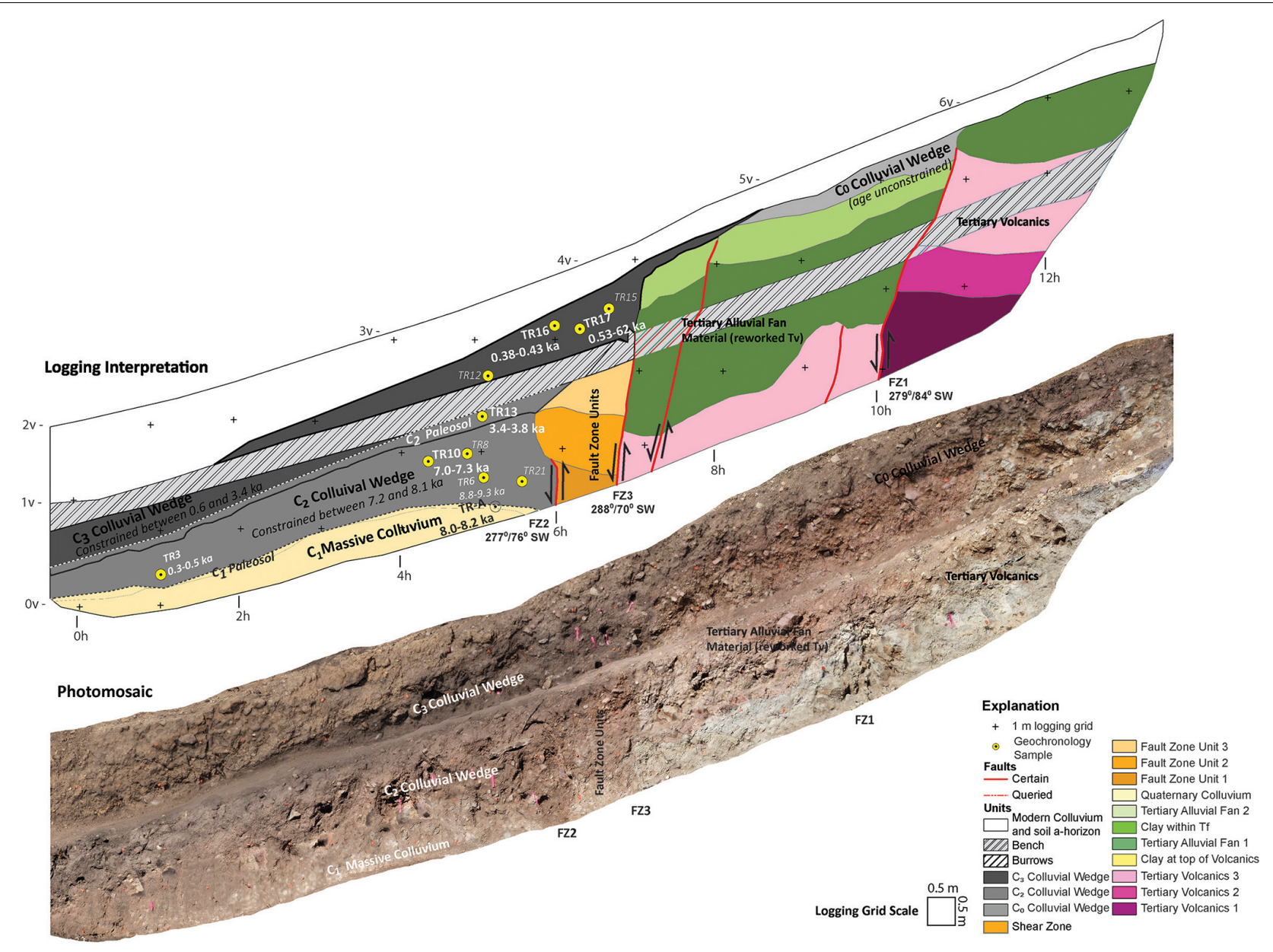

FIGURE 4 | Trench One North (T1N) west wall presents evidence for three earthquake-produced colluvial wedges $\left(\mathrm{C}_{0}, \mathrm{C}_{2}\right.$, and $\left.\mathrm{C}_{3}\right)$ along three fault zones. Ages are constrained for the $\mathrm{C}_{2}$ and $\mathrm{C}_{3}$ events. Samples TR16 (0.3 - $\left.0.4 \mathrm{ka}\right)$, TR17 (0.5-0.6 ka), and TR13a/b (3.4 - $3.5 \mathrm{ka}$ and $\left.3.6-3.8 \mathrm{ka}\right)$ help constrain the age of the event that produced $\mathrm{C}_{3}$. Samples TR10a $(7.0-7.3 \mathrm{ka})$, TR6 $(8.8-9.3 \mathrm{ka})$, and TR-A $(8.0-8.2 \mathrm{ka})$ help constrain the age of the event associated with $\mathrm{C}_{2}(\mathrm{Figures} 7$, 8 and Table 1). Stratigraphic relations of supporting samples are observed on the T1N east wall (Figure 3). Undated samples are shown in italics and smaller font.

thin package of fault-derived colluvium $\left(\mathrm{C}_{0}\right)$ was deposited across a fault zone within the footwall (FZ1). The hanging wall lithology is composed of scarp-derived, matrix-supported colluvium. Three distinct packages of colluvium were identified within the hanging wall of the T1N exposure $\left(C_{1}-C_{3}\right)$. The lowermost of these matrix-supported units $\left(C_{1}\right)$ was massive, highly weathered, clay-dominant colluvium with sparse, angular pebble- to cobble-sized volcanic clasts. Based upon field observations, this unit had the highest soil plasticity of the three colluvial packages. The $\mathrm{C}_{1}$ colluvium is likely associated with a paleoearthquake, but $\mathrm{C}_{1}$ extends below the depth of the trench, so its relationship to an age-controlled faulting event is uncertain. Two additional hanging wall packages of colluvium were deposited above $C_{1}$. Both younger colluvial packages $\left(C_{2}\right.$ and $\mathrm{C}_{3}$ ) were derived from eroded fault scarp free faces, and each was overprinted with soil development, including a recognizable A-horizon indicating a period of relative slope stability after the packages of fault-scarp-derived colluvium were deposited across the fault.
Three fault zones containing evidence for recent earthquakes were identified within $\mathrm{T} 1 \mathrm{~N}$, at meters $9.5-10$ (FZ1 - oldest activity), meter 6 (FZ2), and meter 7 (FZ3 - youngest activity). Each of these fault zones extends upward into discrete faultscarp-derived colluvial packages $\left(\mathrm{C}_{0}, \mathrm{C}_{2}\right.$, and $\mathrm{C}_{3}$ - numbers increasing toward more recent events), which we infer to be colluvial wedge deposits that formed following surface ruptures along the FCSB (Table 3). The colluvial wedge overlying FZ1 $\left(\mathrm{C}_{0}\right)$ is thin $(0-50 \mathrm{~cm})$, located within the footwall stratigraphy, and is composed of angular clasts ranging from coarse sand to small cobbles. Unlike the colluvial wedges identified within the hanging wall, $\mathrm{C}_{0}$ is more clast supported and does not include A-horizon soil development. Because of the lack of organics and evidence of soil A-horizon material within $\mathrm{C}_{0}$, we infer that it is the oldest of the fault-derived colluvial packages. The colluvial wedges overlying FZ2 and FZ3 $\left(\mathrm{C}_{2}\right.$ and $\mathrm{C}_{3}$, respectively) are filled with colluvium that is generally darker in color than the $\mathrm{C}_{0}$ colluvial wedge. $\mathrm{C}_{2}$ and $\mathrm{C}_{3}$ are matrix supported and contain angular clasts of volcanic rocks, ranging in size from pebbles 


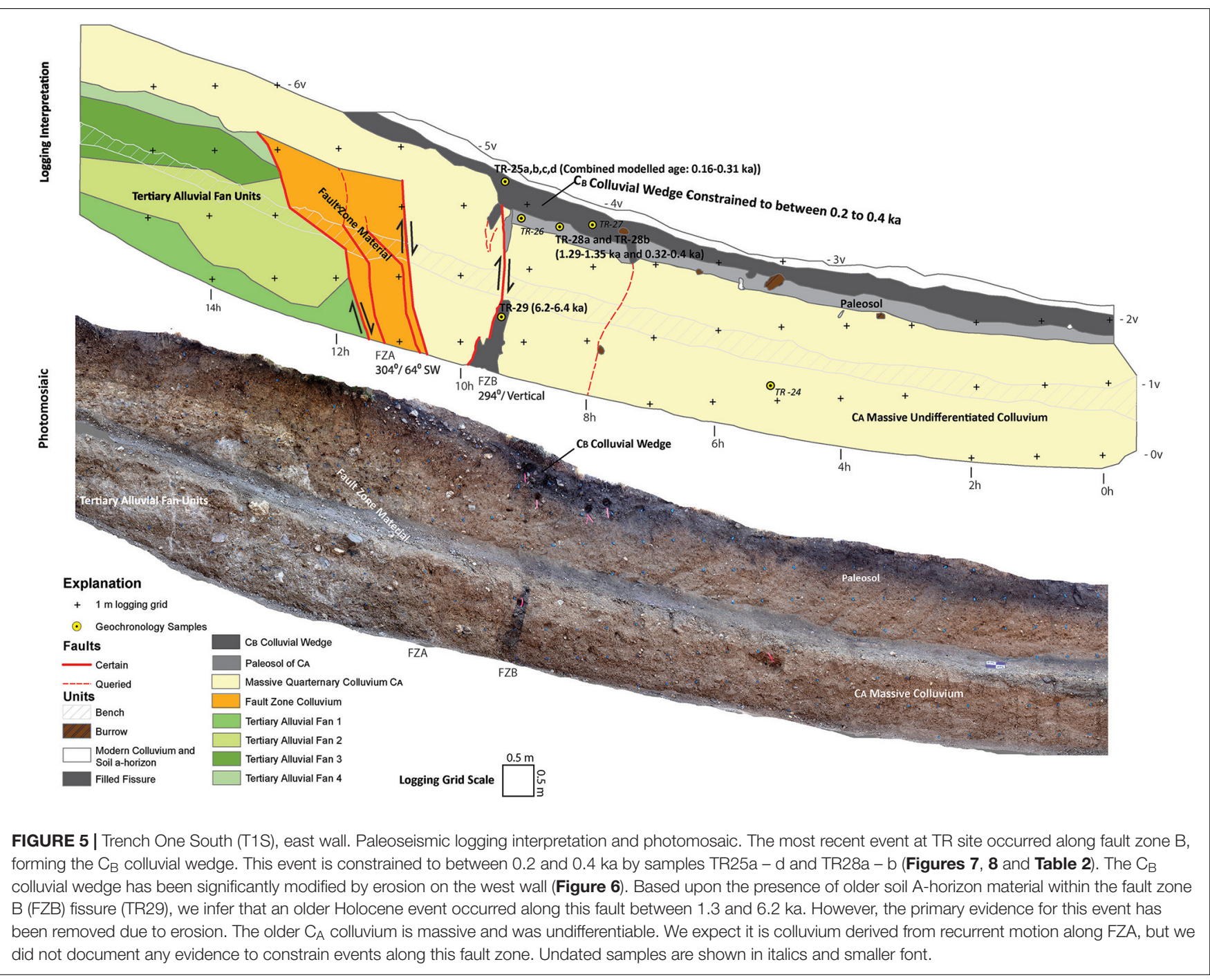

to cobbles. The larger clasts within $\mathrm{C}_{2}$ and $\mathrm{C}_{3}$ are generally more abundant near the base of the deposits. The upper part of $\mathrm{C}_{2}$ retains some character of a buried soil A-horizon, which helped distinguish the unit from the base of $\mathrm{C}_{3}$. Additionally, $\mathrm{C}_{2}$ is grayer in color than that of the overlying $\mathrm{C}_{3}$ deposit. $\mathrm{C}_{3}$ is close in color to the dark modern A-horizon of the Mollisol located on the footwall side of the fault. The top of $\mathrm{C}_{3}$ grades into the modern soil.

The oldest evidence for paleoseismicity at the TR site occurs along FZ1 in T1N (Figures 3, 4). Fault zone 1 strikes $279^{\circ}$ and dips $84^{\circ}$ to the southwest. An earthquake along FZ1 resulted in the deposition of the $\mathrm{C}_{0}$ colluvial wedge. We attribute the lack of reworked soil A-horizon material within the $\mathrm{C}_{0}$ colluvial wedge to its age and position above the recently active part of the fault scarp. Because of this position and an unconformity at the top of $\mathrm{C}_{0}$, we infer that any A-horizon deposited within the colluvial wedge was altered away from biological and soil weathering processes or it was eroded away with recurrent uplift and erosion across the footwall side of the fault scarp. Today, $\mathrm{C}_{0}$ is overlain by $\sim 40-50 \mathrm{~cm}$ of younger slope-derived colluvium which has a well-developed soil A-horizon. A single bulk soil sample was collected from within the $\mathrm{C}_{0}$ colluvial wedge, but this sample did not yield any datable material, so we are unable to constrain the timing of the earthquake responsible for the scarp erosion and production of $\mathrm{C}_{0}$. However, given its position within the footwall, directly overlying reworked Tertiary volcanic rock and the absence of organic soil material within the colluvial wedge, we infer that it is older than the events associated with $\mathrm{C}_{2}$ and $\mathrm{C}_{3}$, possibly prior to the Holocene.

The oldest event that is age constrained within T1N occurred along FZ2 and resulted in the deposition of the $\mathrm{C}_{2}$ colluvial wedge (Event 4: Figure 7 and Table 3). FZ2 strikes $277^{\circ}$ and dips $76^{\circ}$ to the southwest. This fault zone presents evidence for shear due to faulting that extends from the trench floor to about $\sim 10 \mathrm{~cm}$ above the contact between $C_{1}$ and $C_{2}$. Above $10 \mathrm{~cm}$, the fault scarp free face was eroded back and progressively buried by the $\mathrm{C}_{2}$ colluvium. Radiocarbon sample TR-A (charcoal pieces) was collected within the faulted paleosol along a small fissure at the boundary of the $C_{1}$ and $C_{2}$ colluvial deposits. This sample was collected during the reconnaissance study of Toké et al. (2013). 


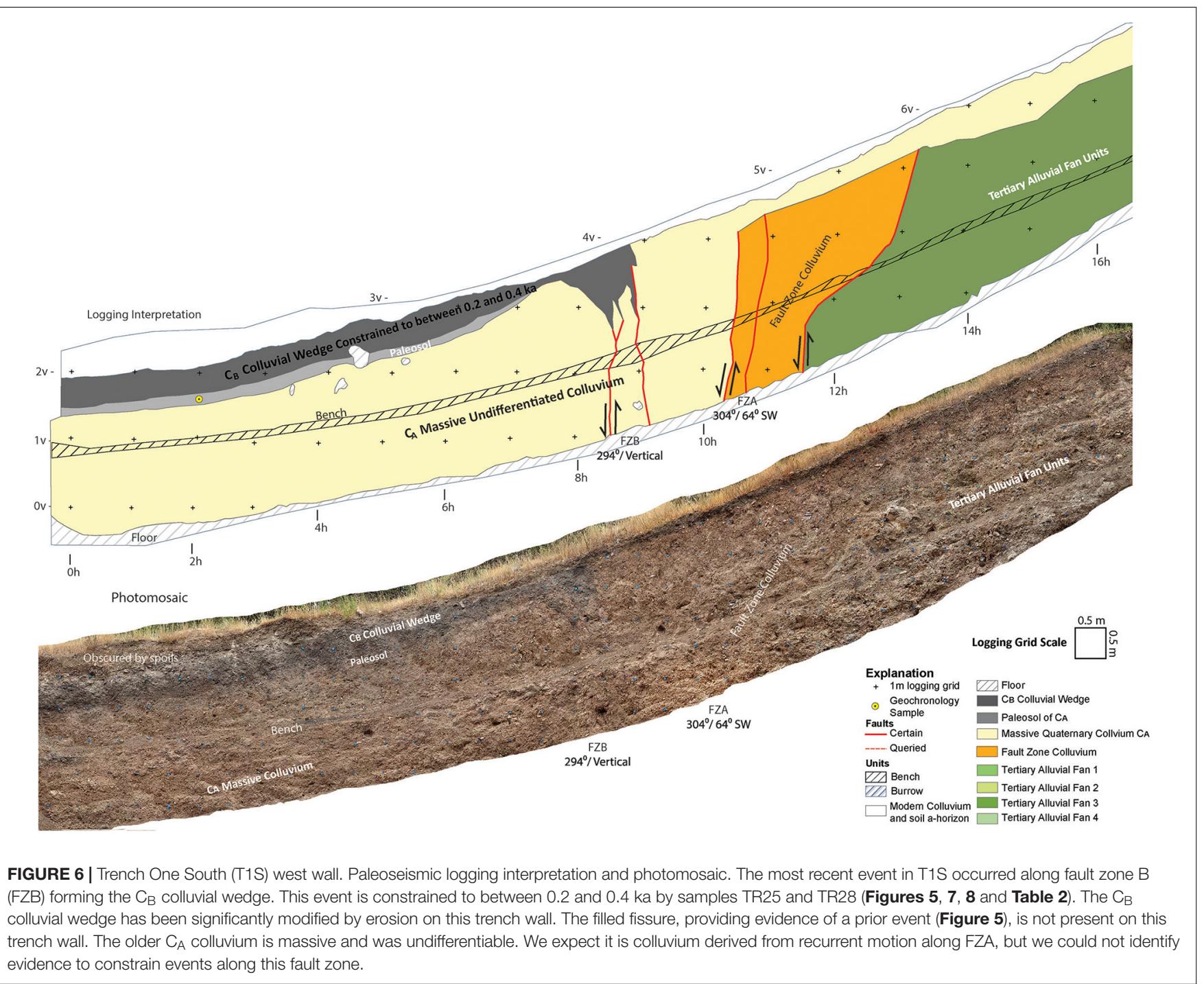

We infer that this charcoal originated from the soil which existed at the time of the penultimate event in T1N and constrains the maximum age of $\mathrm{C}_{2}$ to $\sim 8.0-8.2 \mathrm{ka}$. Radiocarbon sample TR10a was collected within the middle of $\mathrm{C}_{2}$, about $40 \mathrm{~cm}$ above the base of the colluvial wedge, indicating that it accumulated within the soil after the occurrence of the $\mathrm{C}_{2}$ event and constrains the minimum age to before $\sim 7.0-7.3 \mathrm{ka}$ (Figure 7 and Tables 1, 3). Three additional samples (TR3, TR4, and TR6) were dated within the $\mathrm{C}_{2}$ deposit, but they are not useful for constraining events. TR3 was a piece of charred organic material found on the west wall (Figure 4). It yielded an unexpectedly young age of 0.3$0.5 \mathrm{ka}$. Therefore, we infer that it is either root material or was bioturbated into place. TR4 was a piece of charcoal found on the east wall of T1N (Figure 3). It yielded a calibrated age of 13.8-14.8 $\mathrm{ka}$, which is older than any other age from T1N; thus, we infer that the TR4 sample had a relatively long history on the landscape, prior to its deposition within $\mathrm{C}_{2}$, and we do not consider this detrital age to be useful in constraining the age of any events in T1N. TR6 was also a piece of charcoal found on the east wall of
T1N (Figure 3). Though stratigraphically above TR-A, it yielded an age that was significantly older (8.8-9.3 ka) than TR-A. We infer that TR6 has a significant detrital history, and thus it is not used to constrain the event found along FZ2.

The youngest event constrained along the northern fault trace (T1N) occurred along FZ3 (Event 2: Figure 7 and Table 3). This fault strikes $288^{\circ}$ and dips $70^{\circ}$ to the southwest. FZ3 juxtaposes the footwall units against the $C_{3}$ colluvium. There is evidence for shear along the fault surface for $\sim 50 \mathrm{~cm}$ above the base of $\mathrm{C}_{3}$, beyond which the scarp is eroded back and buried by the $\mathrm{C}_{3}$ colluvium which overlies the paleosol at the top of $\mathrm{C}_{2}$. Charred radiocarbon samples TR13a $(\sim 3.4 \mathrm{ka})$ and TR13b (3.6-3.8 ka) were extracted from a bulk soil sample within this paleosol. The younger of these ages, with the least detrital signal representing time spent on the landscape prior to deposition, constrains the maximum age of $\mathrm{C}_{3}$ to after $\sim 3.4$ ka. Three charcoal samples including TR7 (0.4-0.5 ka), TR 16 $(\sim 0.4 \mathrm{ka})$, and TR17 (0.5-0.6 ka) were collected from within the $\mathrm{C}_{3}$ colluvial wedge (Table 1). Together, these samples constrain 
Traverse Ridge Site Modeled Event Ages, Wasatch Fault Zone

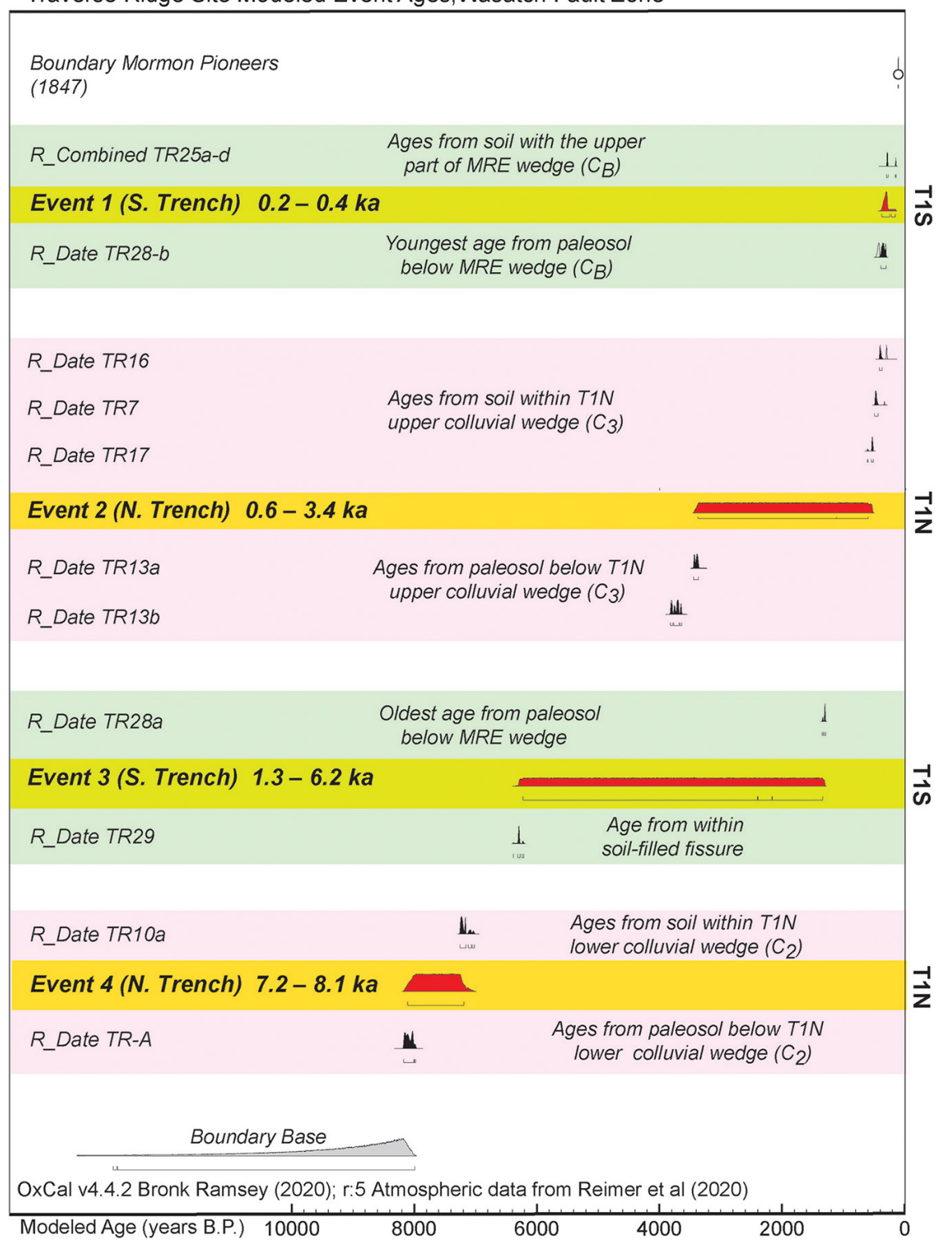

FIGURE 7 | OxCal model (e.g., Lienkaemper and Bronk Ramsey, 2009; Bronk Ramsey, 2017) for TR site event ages are constrained by geochronology samples from bounding stratigraphic units within trench T1S (green shading) and trench T1N (pink shading). Geochronology ages (Tables 1, 2) were modeled either as single ages as a part of an overall sequence of events (i.e., TR-A, TR10a, TR29, TR28a, and TR28b), as a sequence within a stratigraphic unit (i.e., TR-13b, TR13a, TR17, TR7, and TR16), or as a combined age group (TR25a, TR25b, TR25c, and TR25d). The upper boundary of 1847, when Mormon Pioneers entered the region-and no strong earthquakes were felt-is used to help constrain the combined age of TR25 and therefore also helps constrain the age of the most recent earthquake (Event 1). Event ages, rounded to the nearest $0.1 \mathrm{ka}$, are presented here. Full $2 \sigma$ modeled event ages are presented in Table 3. Evidence for Event 2 and Event 3 is from separate trenches and has overlapping age probability distribution functions. Therefore, we cannot be certain if these are the same event or separate events.

the minimum age for the deposition of the $\mathrm{C}_{3}$ colluvium to before $\sim 0.6 \mathrm{ka}$.

\section{Trench 1 South Stratigraphy and Faulting Events}

The south trench (T1S: Figures 5, 6, and Table 2) was reexcavated across a $\sim 215$-m-long fault trace that is about 175 $\mathrm{m}$ southwest of $\mathrm{T} 1 \mathrm{~N}$. This southern fault trace trends $290^{\circ}$ and the scarp faces southwest. To the west of the TR site, the south fault trace intersects and appears to topographically displace (crosscut) the northern fault (Figure 2). The re-excavation of T1S extended horizontally for more than $20 \mathrm{~m}$ and to a maximum depth of $2.5 \mathrm{~m}$ below the ground surface. The excavation was centered on the two primary fault zones FZA (older) and FZB (younger) observed within T1S during the investigation of Toké et al. (2017). 


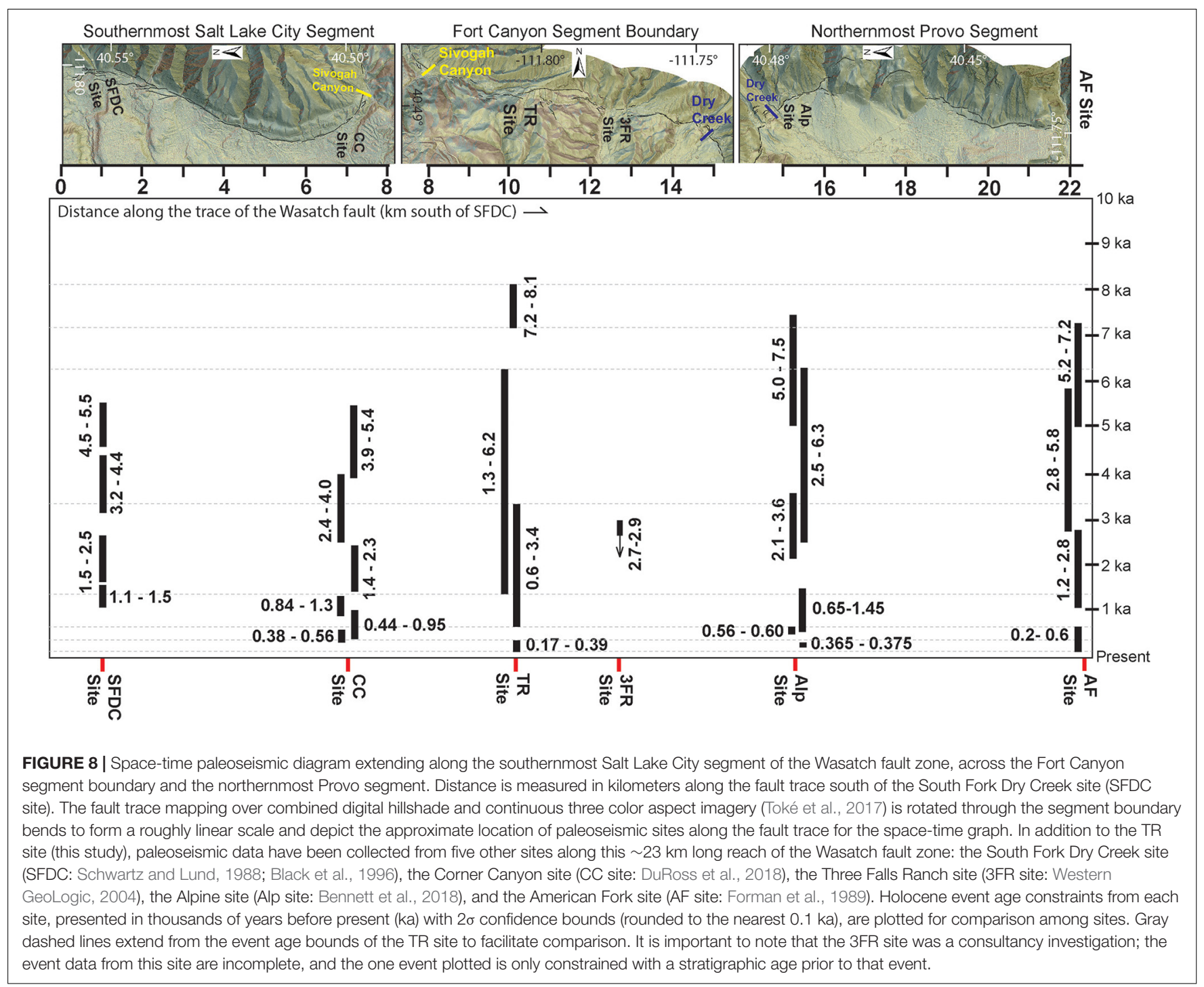

Fault zone A crops out at meter 11 (Figures 5, 6) within T1S, strikes $304^{\circ}$, dips $64^{\circ}$ to the southwest, and juxtaposes footwall Tertiary alluvial fan deposits (e.g., Biek, 2005) against massive fault-scarp-derived, matrix-supported colluvium in the hanging wall $\left(\mathrm{C}_{\mathrm{A}}\right)$. The Tertiary alluvial fan deposits contain a significant component of soil carbonate which has coated some clasts completely. Calcium carbonate has infilled preexisting ground cracks within the footwall units and occurs as nodules within the matrix of the footwall lithology.

The massive hanging wall colluvium $\mathrm{C}_{\mathrm{A}}$ is faulted by FZB at meter 9.5. Here, FZB strikes $294^{\circ}$ and is nearly vertical, dipping more than $85^{\circ}$ to the southwest (Figures 5, 6). A fissure is filled with old A-horizon soil material along FZB (Figure 5). The fault zone extends from the base of the trench to $\sim 70 \mathrm{~cm}$ below the present-day ground surface. Clasts from footwall units and near-surface soil A-horizon material were deposited across the displaced paleo ground surface forming a prominent colluvial wedge $\left(C_{B}\right)$, which formed following the most recent event (MRE) along the southern fault trace (Event 1: Figure 7 and
Table 3). Bulk soil samples were collected from the filled fissure (TR29), from the paleosol A-horizon below the $C_{B}$ colluvial wedge (TR28), and within $C_{B}$ (TR25). The bulk samples were processed to identify and extract datable material. Four separate samples of charred material were dated from within the MRE colluvial wedge (TR25a - d: Figure 5 and Table 2). These samples constrain the minimum age of the $C_{B}$ colluvial wedge to before $0.2-0.3 \mathrm{ka}$. Charred plant remains were dated from two samples within the pre-MRE paleosol (TR28a and TR28b) to constrain the maximum age of the MRE (Event 1 ) along the southern fault trace. TR28a yielded a much older, and presumably detrital age result $(1.3-1.4 \mathrm{ka})$, whereas TR28b is much younger $(0.3-0.4$ ka) and represents a maximum constraint for the MRE. The dated material from within the fissure yielded a much older date than the MRE (6.2 - 6.4 ka: Table 1). This result is interpreted as an infilling of older soil material within the fissure during a prior event (Event 3 ) along the southern fault trace. This event is constrained to have occurred between 1.4-6.2 ka in our model (Figure 7 and Table 3). However, it is possible that this event 
TABLE 1 | T1N radiocarbon data arranged by stratigraphic order.

\begin{tabular}{|c|c|c|c|c|c|c|c|c|c|c|}
\hline $\begin{array}{l}\text { Trench 1N } \\
\text { Sample ID }\end{array}$ & $\begin{array}{c}\text { NSF- } \\
\text { NOSAMS\# }\end{array}$ & Sample Type & $\begin{array}{c}\text { Trench and } \\
\text { Coordinate } \mathrm{s}(\mathrm{X}, \mathrm{Y})^{2}\end{array}$ & Unit & $\begin{array}{l}\text { Fraction } \\
\text { Modern }\end{array}$ & $\pm^{3}$ & $\begin{array}{l}{ }^{14} \mathrm{C} \text { age } \\
\text { (years BP) }\end{array}$ & $\pm^{4}$ & $\begin{array}{l}\text { Unmodelled 2o } \\
\text { calibrated age yBP }\end{array}$ & $\begin{array}{c}\text { Modeled 20 } \\
\text { calibrated age yBP }\end{array}$ \\
\hline TR16 UVU2016 & 142559 & Charcoal Piece & T1N - WW $(6.05,3.25)$ & Upper $\mathrm{C}_{3}$ wedge & 0.9653 & 0.0020 & 285 & 15 & 295-428 увР & 379-429 увР \\
\hline TR7 UVU2016 & 142558 & Charcoal Piece & T1N - EW $(5.80,3.47)$ & Upper $\mathrm{C}_{3}$ wedge & 0.9519 & 0.0020 & 395 & 15 & 335-503 увР & 449-503 увР \\
\hline TR17 UVU2016 & 142560 & Charcoal Piece & T1N - WW $(6.25,3.16)$ & Middle $\mathrm{C}_{3}$ wedge & 0.9347 & 0.0020 & 545 & 15 & 525-624 yВP & 525-623 yВР \\
\hline TR13a UVU2016 & 144287 & Charred Wood pieces & T1N - WW $(5.00,2.20)$ & PRE MRE Soil, top $\mathrm{C}_{2}$ & 0.6733 & 0.0015 & 3180 & 20 & 3369-3448 уВР & 3368-3449 yВР \\
\hline TR13b UVU2016 & 144295 & $\begin{array}{l}\text { Charred unidentified } \\
\text { pieces }\end{array}$ & $\mathrm{T} 1 \mathrm{~N}-\mathrm{WW}(5.00,2.20)$ & PRE MRE Soil, top $\mathrm{C}_{2}$ & 0.6500 & 0.0017 & 3460 & 20 & 3642-3828 уВР & 3641-3828 уВР \\
\hline TR6 UVU2016 & 142557 & Charcoal Piece & $\operatorname{T1N}-\operatorname{WW}(4.99,1.86)$ & Middle $C_{2}$ Wedge & 0.3652 & 0.0021 & 8,090 & 45 & $8777-9260$ yВP & - \\
\hline TR10a UVU2016 & 144286 & $\begin{array}{c}\text { Charred Hardwood } \\
\text { pieces }\end{array}$ & T1N - WW $(4.25,1.80)$ & Middle $\mathrm{C}_{2}$ Wedge & 0.4440 & 0.0015 & 6520 & 25 & 7023-7258 уВР & 7023-7257 уВР \\
\hline TR4 UVU2016 & 142556 & Charcoal Piece & $\operatorname{T1N}-E W(2.65,1.43)$ & Middle C2 Wedge & 0.2202 & 0.0023 & 12,150 & 85 & 13796-14761 уВР & - \\
\hline TR-A UVU2015 & 142561 & Charcoal Piece & T1N-2014 & Base of $\mathrm{C}_{2}$ Wedge & 0.4051 & 0.0020 & 7,260 & 40 & 7980-8175 уВР & 7980-8175 уВР \\
\hline TR3 UVU2016 & 142555 & Charred Piece (root) & $T 1 N-W W(0.80,0.35)$ & Within $C_{1}$ Colluvium & 0.9573 & 0.0019 & 350 & 15 & $318-475$ yBP & - \\
\hline
\end{tabular}

Pretreatment and analyses were performed at the Woods Hole NOSAMS lab. Bold samples help constrain event ages. Italicized samples are younger or older than expected based upon stratigraphic relationships and not utilized in age modeling (Figure 7 and Table 3). TR3 may be a root that died as a result of burial from the MRE wedge. TR4 and TR6 may have had a long history on the landscape prior to deposition. Calibrated ages within the text and figures are quoted to two significant digits in thousands of years ago (ka).

(1) ()Assigned sample name based upon: (A) the year collected, (B) the site name, and (C) the order of collection.

(2) ()Samples Location by trench number and wall and coordinates (X-Horizontal, $Y$-Vertical) bottom-south corner is the origin.

(3) ()Error value (2б) assessed in the calculation of the modern fraction.

(4) ()Error value (2 $\sigma)$ assessed in the calculation of ${ }^{14} \mathrm{C}$ years before present.

(5) ()Determined using single samples in OxCal 4.4 (Bronk Ramsey and Lee, 2013; Bronk Ramsey, 2017) using the IntCal20 calibration curve of Reimer et al. (2020).

TABLE 2 | T1S radiocarbon data arranged by stratigraphic order.

\begin{tabular}{|c|c|c|c|c|c|c|c|c|c|c|}
\hline $\begin{array}{l}\text { Trench1S Sample } \\
\text { ID }^{1}\end{array}$ & $\begin{array}{c}\text { NSF- } \\
\text { NOSAMS\# }\end{array}$ & Sample Type & $\begin{array}{c}\text { Trench and } \\
\text { Coordinates }(\mathrm{X}, \mathrm{Y})^{2}\end{array}$ & Unit & $\begin{array}{l}\text { Fraction } \\
\text { Modern }\end{array}$ & $\pm^{3}$ & ${ }^{14}$ Cage (y BP) & \pm 4 & $\begin{array}{c}\text { Uranodelled } 20 \\
\text { calibrated age (y BP) }\end{array}$ & $\begin{array}{c}\text { Modeled 2o } \\
\text { calibrated age (y BP) }\end{array}$ \\
\hline TR25a UVU2016 & 144288 & charcoal & T1S - EW $(9.90,4.26)$ & MRE $C_{B}:$ Middle & 0.9663 & 0.0020 & 275 & 15 & 289-426 yВР & \\
\hline TR25b UVU2016 & 144289 & charcoal & T1S - EW $(9.90,4.26)$ & MRE $C_{B}$ : Middle & 0.9741 & 0.0028 & 210 & 25 & Modern-305 yBP & 155-309 увР \\
\hline TR25c UVU2016 & 144290 & charcoal & T1S - EW $(9.90,4.26)$ & MRE $C_{B}$ : Middle & 0.9789 & 0.0020 & 170 & 15 & Modern-285 yBP & $\begin{array}{l}\text { (Modeled as one age } \\
\text { R_Combine in OxCal) }\end{array}$ \\
\hline TR25d UVU2016 & 144291 & charcoal & T1S - EW $(9.90,4.26)$ & MRE $C_{B}$ : Middle & 0.9620 & 0.0020 & 310 & 15 & 307-436 уВР & \\
\hline TR28b UVU2016 & 144293 & charcoal & T1S - EW (8.99, 3.60) & $\begin{array}{c}\text { Paleosol below } \\
\text { MRE }\end{array}$ & 0.9583 & 0.0020 & 340 & 15 & 316-469 увР & 318-404 yВР \\
\hline TR28a UVU2016 & 144292 & charcoal & T1S - EW (8.99, 3.60) & $\begin{array}{c}\text { Paleosol below } \\
\text { MRE }\end{array}$ & 0.8403 & 0.0017 & 1400 & 15 & 1289-1345 yВP & 1289-1345 уВР \\
\hline TR29 UVU2016 & 144294 & charcoal & T1S - EW $(9.40,2.30)$ & $\begin{array}{l}\text { Soil material in } \\
\text { fissure }\end{array}$ & 0.5048 & 0.0014 & 5490 & 20 & 6215-6385 yВР & $6215-6383$ уВР \\
\hline
\end{tabular}

Pretreatment and analyses were performed at the Woods Hole NOSAMS lab. Calibrated and modeled ages within the text and figures are quoted to two significant digits in thousands of years before present (ka).

(1) ()Assigned sample name based upon: (A) the year collected, (B) the site name, and (C) the order of collection.

(2) () Samples Location by trench number and wall and coordinates (X-Horizontal, Y-Vertical) bottom-south corner is the origin.

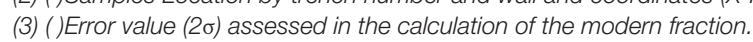

(4) () Error value (26) assessed in the calculation of ${ }^{14} \mathrm{C}$ years before present.

(5) ()Determined using single samples in OxCal 4.4 (Bronk Ramsey and Lee, 2013; Bronk Ramsey, 2017) using the IntCal20 calibration curve of Reimer et al. (2020). 
may be complementary evidence of Event 2 (observed in T1N). Importantly, while it is clear from the fault scarp height at T1S (Figure 2), footwall shear zone (FZA), and massive colluvium $\left(C_{A}\right)$ that recurrent faulting has occurred across the T1S fault scarp, no good evidence was observed to differentiate $C_{A}$ and constrain older events along the southern fault trace.

\section{DISCUSSION}

\section{Interpretations of the Earthquake Record at the TR Site}

The TR site presents evidence for four earthquake-derived colluvial wedges and one earthquake-produced filled fissure within two paleoseismic exposures on sub-parallel fault traces that cut footwall rock types of disparate age and origin (Table 3 ). Addressing event correlations between the two trenches presents challenges. T1N presents scarp-derived colluvial wedge evidence for three separate earthquake events: two events along the main fault zone and one undated event that is preserved within the footwall deposits. T1S presents colluvial wedge evidence constraining one recent Holocene event and fissure fill evidence of a second older event, but the morphology of the fault scarp and massive fault zone colluvium points to other, possibly recent, events that ruptured this fault trace and are not preserved in the TR site paleoseismic record. This possibility of an incomplete record is an important consideration for comparisons with the earthquake record of nearby sites.

At least three, and possibly four, distinct paleoseismic events are certain and broadly constrained by the TR site's record (Figure 7 and Table 3). The MRE (Event 1) occurred between 0.2 and $0.4 \mathrm{ka}$ on the southern fault trace. The penultimate event (Event 2) ruptured the northern fault trace and is broadly constrained between 0.6 and $3.4 \mathrm{ka}$. From evidence of a filled fissure, we infer a third earthquake (Event 3) between 1.4 and $6.2 \mathrm{ka}$ on the southern fault trace; however, this could also be interpreted as additional evidence of Event 2 having ruptured the southern fault trace. The oldest constrained earthquake (Event 4) at the TR site occurred on the northern fault trace between 7.2 and $8.1 \mathrm{ka}$.

If we consider the full range of age uncertainties, there is a very minor chance that the ages for Events 1 and 2 overlap (Tables 1, 2). However, we are fairly certain that the youngest event in $\mathrm{T} 1 \mathrm{~N}$ is the penultimate event at the TR site for the following reasons. First, the ages within $\mathrm{C}_{3}$, which are event minimum ages, are similar to the ages constraining the pre-MRE paleosol on the southern fault trace, which are event maximum ages. Second, the age gap between radiocarbon samples within the paleosol developed prior to the $C_{3}$ colluvial wedge and the radiocarbon samples from within $\mathrm{C}_{3}$ is approximately 3000 years. This indicates that from the available geochronology data, there is much greater probability that the event ages on these two fault traces do not correlate. Third, where the two fault traces intersect, to the west of trench 1 , it appears that the southern fault trace crosscut the northern fault trace (Figure 2C) in the most recent earthquake. Finally, at the $2 \sigma$ probability level, our event modeling does not support this conclusion (Figure 7 and

Table 3). In summary, our preferred interpretation for the event chronology at the TR site is (Table 3 ):

- Most Recent Event (Event 1):

- Penultimate Event (Event 2):

- Event 3:

- Event 4:

$$
\begin{aligned}
& 0.2-0.4 \mathrm{ka} \\
& 0.6-3.4 \mathrm{ka} \\
& 1.4-6.2 \mathrm{ka} \\
& 7.2-8.1 \mathrm{ka}
\end{aligned}
$$

It is important to note that we don't refer to the two older events (Events 3 and 4) as antepenultimate or preantepenultimate, because we suspect that other event(s) may have occurred along the FCSB that were not preserved at the TR site due to erosion of the fault scarp evidence. The southern fault scarp at the TR site is among the most prominent within the segment boundary (Toké et al., 2017) - with more than $12 \mathrm{~m}$ of topographic relief, a maximum scarp slope exceeding $20^{\circ}$, and at least $\sim 20 \mathrm{~m}$ of apparent geomorphic surface displacement (Figure 2B). We infer that it is unlikely that only two Holocene events occurred on this trace of the fault. Furthermore, along the northern fault trace, we documented two fault-derived colluvial packages $\left(\mathrm{C}_{0}\right.$ and $\left.\mathrm{C}_{1}\right)$ that occurred prior to Event 4 but have no geochronology age constraints. These are possibly Holocene events. Therefore, we suspect that the TR site earthquake record is incomplete over the entire Holocene and possibly incomplete since $7 \mathrm{ka}$.

\section{Estimating Magnitudes, Fault Rupture Length, and Segment Connectivity}

Colluvial wedge height maximum thicknesses (Figures 3-6 and Table 3) provide lower limits for vertical displacement in past earthquakes along the Fort Canyon fault. The four colluvial wedges identified within $\mathrm{T} 1 \mathrm{~N}$ and $\mathrm{T} 1 \mathrm{~S}$ ranged in height from 0.5 to $1.2 \mathrm{~m}$. Given these displacement minimums, and considering the empirical relationships among rupture parameters and magnitude (e.g., Wells and Coppersmith, 1994), we infer that all of the Holocene events at the TR site were greater than $\mathrm{M}_{\mathrm{W}} 6.6$, and the largest of these colluvial wedges might be indicative of an earthquake equivalent to or exceeding $\mathrm{M}_{\mathrm{w}} 7.0$ (Table 3). These displacements are comparable to the displacement ranges observed at the two adjacent paleoseismic sites $(0.5-1.3 \mathrm{~m} /$ event at the Alpine site and $0.5-1.4 \mathrm{~m} /$ event at the Corner Canyon site).

Normal faulting earthquakes with these displacement ranges (0.5 - $1.2 \mathrm{~m} /$ event) and magnitudes (M6.6 - M7) should be associated with rupture lengths ranging from at least 11 to more than $27 \mathrm{~km}$ (Table 3: Wells and Coppersmith, 1994; Wong et al., 2016). Given that the slip-per-event data from the TR site are colluvial wedge heights (i.e., minimum estimates), the Holocene surface ruptures along the FCSB likely extended onto one or both of the neighboring fault segments and should be correlative with events recorded at the nearby and recent paleoseismic investigations at the Alpine site (Bennett et al., 2018) and the Corner Canyon site (DuRoss et al., 2018), which are both within $5 \mathrm{~km}$ of the TR site. Furthermore, ruptures approaching M7 could extend beyond the next closest paleoseismic sites such as the South Fork Dry Creek site (10 km north of the TR site on the Salt Lake City segment: Schwartz and Lund, 1988; Black et al., 1996) 
TABLE 3 | Modeled event ages and earthquake inferences for the TR site.

\begin{tabular}{|c|c|c|c|c|c|c|c|c|}
\hline & $\begin{array}{c}\text { Event Age } \\
2 \sigma^{1}\end{array}$ & $\begin{array}{l}\text { Event Age } \\
\text { (rounded) }^{1}\end{array}$ & $\begin{array}{c}\text { Trench } \\
\text { Observed }\end{array}$ & $\begin{array}{l}\text { Fault } \\
\text { Zone }\end{array}$ & $\begin{array}{l}\text { Colluvial } \\
\text { Wedge }\end{array}$ & $\begin{array}{l}\text { Wedge } \\
\text { Height }^{2}\end{array}$ & $\begin{array}{l}\text { Rupture } \\
\text { Length }^{3}\end{array}$ & $\begin{array}{c}\text { Mw } \\
\text { Empirical }^{4}\end{array}$ \\
\hline $\begin{array}{l}\text { Most Recent } \\
\text { Event (MRE) }\end{array}$ & 168-391 & $\begin{array}{c}0.2-0.4 \\
\mathrm{ka}\end{array}$ & T1S & $\mathrm{FZb}$ & $\mathrm{C}_{\mathrm{B}}$ & 0.7 & $16 \mathrm{~km}$ & 6.7 \\
\hline $\begin{array}{l}\text { Penultimate } \\
\text { Event (PE) }\end{array}$ & 610-3375 & $\begin{array}{c}0.6-3.4 \\
\mathrm{ka}\end{array}$ & $\mathrm{T} 1 \mathrm{~N}$ & FZ3 & $\mathrm{C}_{3}$ & 1.2 & $27 \mathrm{~km}$ & 7.0 \\
\hline $\begin{array}{l}\text { Fissure Event in } \\
\text { T1S }\end{array}$ & 1340-6224 & $\begin{array}{c}1.3-6.2 \\
\mathrm{ka}\end{array}$ & T1S & $\mathrm{T} 1 \mathrm{~S}$ & $\mathrm{FZb}$ & $?$ & $?$ & $?$ \\
\hline Older Event & 7193-8107 & $\begin{array}{c}7.2-8.1 \\
\mathrm{ka}\end{array}$ & $\mathrm{T} 1 \mathrm{~N}$ & $\mathrm{FZ2}$ & $\mathrm{C}_{2}$ & 1.1 & 25 km & 6.9 \\
\hline $\begin{array}{l}\text { Unconstrained } \\
\text { Events }\end{array}$ & Unknown & - & T1S & $\mathrm{FZa}$ & $\mathrm{C}_{\mathrm{A}}$ & Unknown & $? ?$ & $? ?$ \\
\hline $\begin{array}{l}\text { Unconstrained } \\
\text { Events }\end{array}$ & $\begin{array}{c}\text { Pre } \\
\text { Holocene }\end{array}$ & - & $C_{1}$ and $C_{0}$ & $\mathrm{~T} 1 \mathrm{~N}$ & FZ1 & 0.5 & $8 \mathrm{~km}$ & 6.6 \\
\hline
\end{tabular}

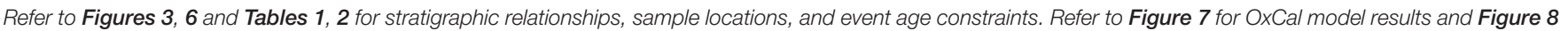
for relationships with other nearby paleoseismic sites along the Wasatch fault.

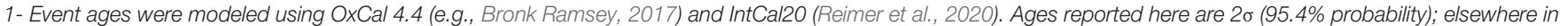
the text and figures, we report ages rounded to the nearest $0.1 \mathrm{ka}$.

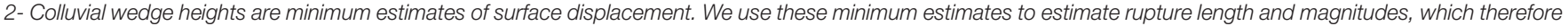
are also likely lower bounds.

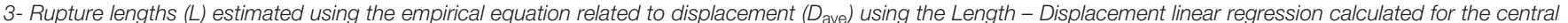
Wasatch fault zone: Wong et al. (2016): $L=D_{\text {ave }} / 0.044$.

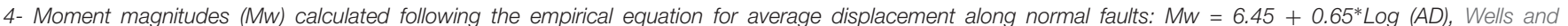
Coppersmith (1994).

and/or the American Fork site $(\sim 13 \mathrm{~km}$ south of the TR site on the Provo segment: Forman et al., 1989).

\section{Comparison of the TR Site With Nearby Paleoseismic Records}

The South Fork Dry Creek site is located $10 \mathrm{~km}$ north of the TR site along the southern Salt Lake City segment (Figures 1, 8). The paleoseismic record at this site includes four events over the last 6000 years $(1.1-1.5 \mathrm{ka}, 1.5-2.5 \mathrm{ka}, 3.2-4.4 \mathrm{ka}$, and $4.5-5.5 \mathrm{ka}$ : Schwartz and Lund, 1988; Black et al., 1996). The American Fork site is located $13 \mathrm{~km}$ south of the TR site along the northern Provo segment and its paleoseismic record includes four events over the last 7000 years $(0.2-0.6 \mathrm{ka}, 1.2-2.8 \mathrm{ka}, 2.8-5.8 \mathrm{ka}$, and $5.2-7.2$ ka: Forman et al., 1989). Comparing the TR site record with these sites on the two adjacent fault segments allows for the following possibilities. The most recent event (Event 1$)$ at the TR site $(0.2-$ 0.4 ka: Figures 7,8 ) can be correlated with the youngest event at the American Fork site, but no young event is correlative at the South Fork Dry Creek site. The penultimate event at the TR site is not well constrained $(0.6-3.4 \mathrm{ka})$ and could be correlated with the penultimate events at both the American Fork and South Fork Dry Creek site. Because of the poor age constraints, it could also be correlated with the antepenultimate events at these sites. Event 3 at the TR site is also poorly constrained and could correlate with the three older events at both the SFDC and AF sites. The oldest event observed at the TR site $(7.4-8.2 \mathrm{ka})$ extends beyond the paleoseismic records of the nearby paleoseismic sites that typically go back 6-7 ka (Figure 8).

Over the last 6000 years, the TR site preserves evidence of two to three surface rupturing earthquakes (Table 3). This finding demonstrates that the TR site records fewer earthquakes than have occurred on the neighboring fault segments since the mid
Holocene. Four events were observed at both the South Fork Dry Creek and American Fork sites. In even greater contrast, the records from the Alpine site on the Provo segment (Bennett et al., 2018) and Corner Canyon site on the Salt Lake City segment (DuRoss et al., 2018) indicate an even greater frequency of events at the endpoints of the neighboring segments. Both sites record six events during this time span (Figure 8). Thus, we observe that the TR site may only record approximately one-half of the ruptures observed at paleoseismic sites on neighboring fault segments.

There are at least four possible explanations for fewer earthquakes at the TR site since the middle Holocene. First, faulting within the FCSB is complex with numerous stepping fault traces and scarps that occur more than a kilometer away from the main Fort Canyon fault trace (e.g., Figure 1; Toké et al., 2017). Therefore, it is possible that ruptures have crossed through the segment boundary without rupturing the TR paleoseismic site due to small ( $\sim 1 \mathrm{~km}$ and less) gaps in the expression of surface rupture, leaving our record incomplete. Second, the Fort Canyon fault clearly has less total displacement than the adjacent fault segments. Along the FCSB mountain salient, Tertiary rocks crop out on the hanging wall with no Quaternary cover hundreds of meters above the nearby valley bottoms that also have significant Quaternary fill. This contrast in apparent displacement corresponds to the expectation that the linkage zones of fault segments should be sites of lower average displacement in individual earthquakes (e.g., Peacock and Sanderson, 1991). Therefore, some unrecorded events may have had small surface displacements (i.e., less than $50 \mathrm{~cm}$ ). Such small ruptures, breaking through the high topography of Traverse Ridge that also includes numerous landslides, would be challenging to preserve in this erosion-dominant part of 
the landscape. Third, ground rupturing earthquakes sometimes have large gaps of multiple kilometers in their surface ruptures (e.g., Biasi and Wesnousky, 2016). A prominent example is the 1983 Borah Peak, Idaho, earthquake which crossed the Willow Creek structural salient with a 5-km-long rupture gap across this segment boundary (e.g., Crone et al., 1987). Therefore, it is possible that ruptures may be recorded at sites on adjacent fault segments (e.g., the Alpine or Corner Canyon sites) but not within an individual paleoseismic site along the segment boundary (e.g., the TR site). Finally, ruptures on the neighboring segments may terminate at or near the segment boundary and given that rupture endpoints tend to have displacement minima, some ruptures may not have propagated to the surface to be recorded at the TR site. This possibility is supported by recent surface trace mapping by the Utah Geological Survey which documents numerous branching fault scarps on the south side of Traverse Ridge (McDonald et al., 2020). These branching fault scarps may represent the termination of some Provo segment ruptures within a damage zone on the south side of the FCSB.

\section{Evaluating Rupture Scenarios}

At this point, the published event chronology data from the TR site and the neighboring parts of the Provo and Salt Lake City segments can help to evaluate a range of rupture scenarios (Figure 8). The most recent event ages observed along the northern Provo segment and the TR site all may have ruptured between 0.2 and $0.6 \mathrm{ka}$. This observation could be used to support the model of a spillover rupture, where much of the Provo segment ruptures and faulting continues north, breaking through the FCSB and possibly spilling over onto the southernmost parts of Salt Lake City segment. The 1983 Borah Peak earthquake is an example of a partial segment rupture with spillover across the segment boundary and onto the adjacent segment, although in that case rupture was minimal within the segment boundary (e.g., Crone et al., 1987; DuRoss et al., 2019). If this hypothesis is true for the most recent event at the TR site, then the Alpine site may constrain the age of this event to a narrow ten-year period about 370 years ago (Bennett et al., 2018).

Full multisegment rupture, breaking most or the entire Salt Lake City segment, the FCSB, and Provo segment is not well supported by the existing paleoseismic data adjacent to this segment boundary, but it cannot be completely excluded. Rupture ages overlap between 2.1 and $2.5 \mathrm{ka}$ across all sites from the South Fork Dry Creek site to the American Fork site (Figure 8), and the third event at the SFDC site can also be correlated along the entire fault length. The paleoseismic data also permit the possibility of segmented rupture, with no rupture through the segment boundary. For instance, the oldest two ruptures on the northernmost Provo segment have, at most, only one correlative event supported by evidence from the TR site (however, this part of the record may be incomplete). Therefore, at least one of these two events possibly did not involve the segment boundary or the southern Salt Lake City segment (Figure 8). Finally, rupture originating from segment boundary faults (i.e., segment boundary ruptures) is supported by the overall higher recurrence rate observed at the Corner Canyon and Alpine sites (six events in $6 \mathrm{ka}$ ) as compared with the South Fork Dry
Creek and American Fork sites (four events in $6 \mathrm{ka}$ ). An example of a segment boundary rupture could be represented by the penultimate events observed at the Corner Canyon, TR, and the Alpine sites, which may have occurred prior to $0.6 \mathrm{ka}$.

The occurrence of segment boundary ruptures and a higher recurrence of earthquakes at or near segment boundaries is not unexpected. An explanation for these observations is that large ruptures on the adjacent fault segments do occur. When these ruptures stop near the segment boundary, it distributes stress in a broad zone that includes the segment boundary (e.g., Chang and Smith, 2002; Bagge et al., 2019; Verdecchia et al., 2019). This stress transfer may result in subsequent smaller surface rupturing events within or next to the segment boundary. Alternatively, the rupture may not stop, but instead it may spill across the segment boundary. With these rupture mechanisms being driven from two sides, the segment boundary itself may experience more surface rupturing earthquakes than the center of the primary fault segments. This is important, because while the slip rate at endpoints of segment boundaries may be less, the frequency of damaging ground shaking may be higher in locations near fault segment boundaries.

\section{The Utility of Paleoseismic Sites Within Segment Boundaries}

The results from the TR site demonstrate that paleoseismic information may be obtained from within the high and varied terrain of normal fault segment boundaries. These data can confirm that spillover and segment boundary ruptures occur. However, the observation of fewer total events at the TR site in comparison to the well-placed Corner Canyon and Alpine sites that sit near the ends of fault segments brings into question whether this paleoseismic setting is adequate to record all events that rupture the segment boundary. Ideally, future attempts at utilizing segment boundary paleoseismic sites should (1) seek out the least complex parts of the fault zone, (2) trench all parallel and sub-parallel traces of the fault zone, and (3) attempt to trench paleoseismic sites with recent and recurrent deposition (e.g., montane basins or alluvial fans) to minimize the potential that paleoearthquake evidence was lost due to erosion. Finally, because of fault complexity and rupture variability, it may be necessary to trench at multiple locations within the segment boundary to obtain the same quality of record as recorded on adjacent segments at a single site. This type of endeavor may require a much larger geochronology budget than is typical for individual paleoseismic sites. Therefore, segment boundary paleoseismic sites are probably best utilized as complementary data to sites placed at the endpoints of fault segments.

\section{CONCLUSION}

At least three to four earthquakes have ruptured the Fort Canyon fault at the TR site during the Holocene. The most recent event occurred along the southern fault trace at the TR site between 0.2 and $0.4 \mathrm{ka}$. The penultimate event ruptured the northern fault trace between 0.6 and $3.4 \mathrm{ka}$. A third event is recorded on the southern fault trace between 1.4 and $6.2 \mathrm{ka}$, although this may be 
complementary evidence of the penultimate event. A fourth event ruptured the northern fault trace between 7.2 and $8.1 \mathrm{ka}$. The paleoseismic history revealed by the TR site shows that during the Holocene about half as many earthquakes were recorded here than the neighboring paleoseismic sites along the Provo and Salt Lake City segments of the WFZ. This may be due to distributed faulting, missing deposits due to erosion at the TR site, gaps in the surface rupture of some paleoearthquakes, or because less total slip reaches the surface within fault segment boundaries. Data from the two sites adjacent to the FCSB (Bennett et al., 2018; DuRoss et al., 2018) discount the notion that fewer earthquakes occur at fault segment boundaries. This study demonstrates the utility of paleoseismology within segment boundaries which, through corroboration of displacement data, can demonstrate rupture connectivity between fault segments, and test the validity of segment boundary rupture scenarios despite the wide uncertainties of most paleoseismic age constraints.

\section{DATA AVAILABILITY STATEMENT}

The original contributions presented in the study are included in the article/supplementary material, further inquiries can be directed to the corresponding author/s.

\section{AUTHOR CONTRIBUTIONS}

NT and JC worked on a preliminary investigation of the Traverse Ridge site in 2013. NT, JP, CL, EK, CD, AH, GM, JW, and DH participated in the 2016 paleoseismic field season. NT, JP, and CL constructed the figures presented herein. NT wrote the manuscript. All authors participated in the editing of the original manuscript.

\section{REFERENCES}

Bagge, M., Hampel, A., and Gold, R. D. (2019). Modeling the Holocene slip history of the Wasatch fault (Utah): coseismic and postseismic Coulomb stress changes and implications for paleoseismicity and seismic hazard. GSA Bull. 131, 43-57. doi: 10.1130/B31906.1

Bemis, S. P., Micklethwaite, S., Turner, D., James, M. R., Akciz, S., Thiele, S. T., et al. (2014). Ground-based and UAV-based photogrammetry: a multiscale, high-resolution mapping tool for structural geology and paleoseismology. J. Struct. Geol. 69, 163-178. doi: 10.1016/j.jsg.2014. 10.007

Bennett, S. E. K., DuRoss, C. B., Gold, R. D., Briggs, R. W., Personius, S. F., Reitman, N. G., et al. (2018). Paleoseismic results from the Alpine site, Wasatch fault zone; timing and displacement data for six Holocene earthquakes at the Salt Lake City-provo segment boundary. Bull. Seismol. Soc. Am. 108, 3202-3224. doi: $10.1785 / 0120160358$

Biasi, G. P., and Wesnousky, S. G. (2016). Steps and gaps in ground ruptures: empirical bounds on rupture propagation. Bull. Seismol. Soc. Am. 106, 11101124. doi: 10.1785/0120150175

Biek, R. F. (2005). Geologic Map of the Lehi Quadrangle and Part of the Timpanogos Cave Quadrangle, Salt Lake and Utah Counties, Utah Geological Survey 7.5' Geological Maps, Utah, M-210. Salt Lake City, UT: Utah Geological Survey.

Black, B. D., Lund, W. R., Schwartz, D. P., Gill, H. E., and Mayes, B. H. (1996). Paleoseismic investigation on the Salt Lake City Segment of the Wasatch Fault Zone at the South Fork Dry Creek and Dry Gulch Sites, Salt Lake County, Utah,

\section{FUNDING}

This research project was supported by a U.S. Geological Survey EHP Award \# G16AP0014 and the Utah Valley University (UVU) College of Science SAC program.

\section{ACKNOWLEDGMENTS}

Initial results of this investigation were released as a final technical report to the U.S. Geological Survey (USGS) Earthquake Hazards Program which funded the study (Toké and Horns, 2017). We thank the City of Draper, Utah and David Simon for assistance with gaining access to the investigation site and developing site management plans. Todd Nelson provided professional excavation service. We received significant field support from Mike Hylland, Greg Beukelman, Utah Geological Survey (UGS) interns from Weber State and Carlton College, Shannon Fell, Christopher Bross, and Paul Bushman. Jim McCalpin shared preliminary logging interpretations from some of the previous consultant trenches at the TR site. UVU Department of Earth Science field camp students from 2013 and 2014 helped with reconnaissance mapping and paleoseismic exploration at the TR site. Bulk soil charcoal extractions were processed at PaleoResearch Institute located in Golden, Colorado, and Radiocarbon analyses were performed by the NOSAMS facility. We are grateful for early reviews of this manuscript by the UGS and USGS and for peer reviews from B. Philibosian, H. Kelsey, R. Jayangonda Perumal, and USGS editorial review from J. Slate, which all substantially improved the manuscript. Any use of trade, firm, or product names is for descriptive purposes only and does not imply endorsement by the U.S. Government or the authors.

Paleoseismology of Utah, Utah Geological Survey Special Study 92, Vol. 7. Salt Lake City, UT: Utah Geological Survey, 22.

Bronk Ramsey, C. (2017). Methods for summarizing radiocarbon datasets. Radiocarbon 59, 1809-1833. doi: 10.1017/RDC.2017.108

Bronk Ramsey, C., and Lee, S. (2013). Recent and planned developments of the program OxCal. Radiocarbon 55, 720-730. doi: 10.1017/S0033822200057878

Chang, W., and Smith, R. B. (2002). Integrated seismic-hazard analysis of the Wasatch Front, Utah. Bull. Seismol. Soc. Am. 92, 1904-1922. doi: 10.1785/ 0120010181

Crone, A. J., Machette, M. N., Bonilla, M. G., Lienkaemper, J. J., Pierce, K. L., Scott, W. E., et al. (1987). Surface faulting accompanying the Borah peak earthquake and segmentation of the lost river fault, central idaho. Bull. Seismol. Soc. Am. 77, 739-770.

DuRoss, C. B., Bennett, S. E. K., Briggs, R. W., Personius, S. F., Gold, R. D., Reitman, N. G., et al. (2018). Combining conflicting Bayesian models to develop paleoseismic records: an example from the Wasatch fault zone, Utah. Bull. Seismol. Soc. Am. 108, 3180-3201. doi: 10.1785/0120170302

DuRoss, C. B., Bunds, M. P., Gold, R. D., Briggs, R. W., Reitman, N. G., Personius, S. F., et al. (2019). Variable normal-fault rupture behavior, northern lost river Fault Zone, idaho, USA. Geosphere 15, 1869-1892. doi: 10.1130/GES02096.1

DuRoss, C. B., and Hylland, M. D. (2015). Synchronous ruptures along a major graben-forming fault system-Wasatch and West Valley fault zones, Utah, USA. Bull. Seismol. Soc. Am. 105, 14-37. doi: 10.1785/0120140064

DuRoss, C. B., Hylland, M. D., McDonald, G. N., Crone, A. J., Personius, S. F., Gold, R. D., et al. (2014). "Holocene and latest Pleistocene paleoseismology of the Salt 
Lake City segment of the Wasatch fault zone, Utah, at the Penrose Drive trench site," in Evaluating Surface Faulting Chronologies of Graben-Bounding Faults in Salt Lake Valley, Utah-- New Paleoseismic Data from the Salt Lake City Segment of the Wasatch Fault Zone and the West Valley Fault Zone: Utah Geol. Surv. Spec. Stud. 149, Vol. 24, eds C. B. DuRoss, and M. D. Hylland, (Salt Lake City, UT: Utah Geological Survey), 1-39.

DuRoss, C. B., Personius, S. F., Crone, A. J., Olig, S. S., Hylland, M. D., Lund, W. R., et al. (2016). Fault segmentation: new concepts from the Wasatch fault zone, Utah, USA. J. Geophys. Res. Solid Earth 121, 1131-1157. doi: 10.1002/ 2015JB012519

Field, E. H., Arrowsmith, R. J., Biasi, G. P., Bird, P., Dawson, T. E., Felzer, K. R., et al. (2014). Uniform California earthquake rupture forecast, version 3 (UCERF3)the time-independent model. Bull. Seismol. Soc. Am. 104, 1122-1180. doi: 10. $1785 / 0120130164$

Forman, S. L., Machette, M. N., Jackson, M. E., and Mott, P. (1989). An evaluation of thermoluminescence dating of paleoearthquakes on the American Fork segment, Wasatch fault zone, Utah. J. Geophys. Res. 94, 1622-1630. doi: 10.1029/ JB094iB02p01622

Gilbert, G. K. (1884). A theory of the earthquakes of the Great Basin, with a practical application. Am. J. Sci. Third Ser. XXXVII, 49-53.

Gilbert, G. K. (1928). Studies of Basin and Range Structure: U.S. Geological Survey Professional Paper 153, Reston, VA: USGS, 92. doi: 10.3133/pp153

Graymer, R. W., Langenheim, V. E., Simpson, R. W., Jachens, R. C., and Ponce, D. A. (2007). Relatively simple through-going fault places at large-earthquake depth may be concealed by the surface complexity of strike-slip faults. Geol. Soc. Lond. Spec. Publ. 290, 189-201. doi: 10.1144/SP290.5

Haddon, E. K., Amos, C. B., Zielke, O., Jayko, A. S., and Bürgmann, R. (2016). Surface slip during the large Owens Valley earthquakes. Geochem. Geophys Geosyst. 17, 2239-2269. doi: 10.1002/2015GC006033

Hart, M. W., Shaller, P. J., and Farrand, G. (2012). When landslides are misinterpreted as faults: case studies from the western United States. Environ. Eng. Geosci. 18, 313-325. doi: 10.2113/gseegeosci.18.4.313

Lienkaemper, J. J., and Bronk Ramsey, C. (2009). OxCal: versatile tool for developing paleoearthquake chronologies-a primer. Seismol. Res. Lett. 80, 431-434. doi: $10.1785 /$ gssrl.80.3.431

Lund, W. R., and Black, B. D. (1998). "Paleoseismic Investigation at Rock Canyon, Provo segment, Wasatch Fault Zone, Utah County, Utah," in Paleoseismology of Utah, Utah Geological and Mineral Survey Special Study 93, Vol. 8, ed. W. R. Lund, (Salt Lake City, UT: Utah Geological Survey), 22.

Machette, M. N., Personius, S. F., Nelson, A. R., Schwartz, D. P., and Lund, W. R. (1991). The Wasatch fault zone, Utah-segmentation and history of Holocene earthquakes. J. Struct. Geol. 13, 137-149. doi: 10.1016/0191-8141(91)90062-N

Manighetti, I., Campillo, M., Bouley, S., and Cotton, F. (2007). Earthquake scaling, fault segmentation, and structural maturity. Earth Planet. Sci. Lett. 253, 429438. doi: 10.1016/j.epsl.2006.11.004

McCalpin, J. P. (2002). "Post-bonneville paleoearthquake chronology of the Salt Lake City segment, Wasatch fault zone, from the 1999 "megatrench" site," in Paleoseismology of Utah, Utah Geological Survey Miscellaneous Publication 02-7, Vol. 10, ed. W. R. Lund, (Salt Lake City, UT: Utah Geological Survey), 37.

McCalpin, J. P., and Nishenko, S. P. (1996). Holocene paleoseismicity, temporal clustering, and probabilities of future large $(M>7)$ earthquakes on the Wasatch fault zone, Utah. J. Geophys. Res. 101, 6233-6253. doi: 10.1029/95JB02851

McDonald, G. N., Kleber, E. K., Hiscock, A. I., Bennett, S. E. K., and Bowman, S. D. (2020). Fault Trace Mapping and Surface-Fault Rupture Special Study Zone Delineation of the Wasatch Fault Zone, Utah and Idaho. Utah Geological Survey Report of Investigation 280. Salt Lake City, UT: Utah Geological Survey, 23. doi: $10.34191 / R I-280$

Nelson, M. S., Gray, H. J., Johnson, J. A., Rittenour, T. M., Feathers, J. K., and Mahan, S. A. (2015). User guide for luminescence sampling in archaeological and geological contexts. Adv. Archaeol. Pract. 3, 166-177. doi: 10.7183/23263768.3.2.166

Olig, S. S., McDonald, G. N., Black, B. D., DuRoss, C. B., Lund, W. R., Hylland, M. D., et al. (2011). Extending the Paleoseismic Record of the Provo Segment of the Wasatch Fault Zone, Utah, Final Technical Report to the U.S. Geological Survey. Salt Lake City, UT: Utah Geological Survey, 62.

Pantosti, D., D'Addenzio, G., and Cinti, F. R. (1996). Paleoseismicity of the Ovindoli-Pezza fault, central Apennines, Italy: a history including a large, previously unrecorded earthquake in the middle ages (860-1300 AD). J. Geophys. Res. 101, 5937-5959. doi: 10.1029/95JB03213

Peacock, D. C. P., and Sanderson, D. J. (1991). Displacements, segment linkage and relay ramps in normal fault zones. J. Struct. Geol. 13, 721-733.

Philibosian, B., and Meltzner, A. J. (2020). Segmentation and supercycles: a catalog of earthquake rupture patterns from the Sumatran Sunda Megathrust and other well-studied faults worldwide. Quat. Sci. Rev. 241:106390. doi: 10.1016/ j.quascirev.2020.106390

Prentice, C., and Schwartz, D. P. (1991). Re-evaluation of 1906 surface faulting, geomorphic expression and seismic hazard along the San Andreas fault in the southern Santa Cruz mountains. Bull. Seismol. Soc. Am. 81, 1424-1479.

Reimer, P., Austin, W., Bard, E., Bayliss, A., Blackwell, P., Bronk Ramsey, C., et al. (2020). The IntCal20 Northern Hemisphere radiocarbon age calibration curve (0-55 cal kBP). Radiocarbon 62, 725-757. doi: 10.1017/RDC.2020.41

Reitman, N. G., Bennett, S. E. K., Gold, R. D., Briggs, R. W., and DuRoss, C. (2015). High-resolution trench photomosaics from image-based modeling: workflow and error analysis. Bull. Seismol. Soc. Am. 105, 2354-2366. doi: 10. $1785 / 0120150041$

Sare, R., Hilley, G. E., and DeLong, S. B. (2019). Regional-scale detection of fault scarps and other tectonic landforms: examples from northern california. $J$. Geophys. Res. Solid Earth doi: 10.1029/2018JB016886

Schwartz, D. P., and Coppersmith, K. J. (1984). Fault behavior and characteristic earthquakes: examples from the Wasatch and San Andreas fault zones. J. Geophys. Res. 89, 5681-5698. doi: 10.1029/JB089iB07p05681

Schwartz, D. P., and Lund, W. R. (1988). "Paleoseismicity and earthquake recurrence at Little Cottonwood Canyon, Wasatch fault zone, Utah," in In the Footsteps of G.K. Gilbert: Lake Bonneville and Neotectonics of the Eastern Basin and Range Province: Utah Geological and Mineral Survey Miscellaneous Publication 88-1, ed. M. N. Machette, (Salt Lake City, UT: Utah Geological and Mineralogical Survey), 82-85.

Seitz, G., Weldon, R., and Biasi, G. P. (1997). The Pitman Canyon paleoseismic record: a re-evaluation of southern San Andreas fault segmentaton. J. Geodyn. 24, 129-138. doi: 10.1016/S0264-3707(96)00042-7

Sibson, R. H. (1986). "Rupture interactions with fault jobs," in Earthquake Source Mechanics, Vol. 37, eds S. Das, J. Boatwright, and C. H. Scholtz, (Washington DC: American Geophysical Union Monographs), 157-167.

Sieh, K. (1978). Slip along the San Andreas fault associated with the great 1857 earthquake. Bull. Seismol. Soc. Am. 68, 1421-1428.

Stirling, M., Goded, T., Berryman, K., and Litchfield, N. (2013). Selection of earthquake scaling relationships for seismic-hazard analysis. Bull. Seismol. Soc. Am. 103, 2993-3011. doi: 10.1785/0120130052

Stirling, M., Rhoades, D., and Berryman, K. (2002). Comparison of earthquake scaling relations derived from data of the instrumental and preinstrumental era. Bull. Seismol. Soc. Am. 92, 812-830. doi: 10.1785/0120000221

Swan, F. H. III, Schwartz, D. P., and Cluff, L. S. (1980). Recurrence of moderate to large magnitude earthquakes produced by surface faulting on the Wasatch fault zone, Utah. Bull. Seismol. Soc. Am. 70, 1431-1462.

Taylor, F. W., Briggs, R. W., Frohlich, C., Brown, A., Hornbach, M., Papabatu, A. K., et al. (2008). Rupture across arc segment and plate boundaries in the 1 April 2007 Solomons earthquake. Nat. Geosci. 1, 253-257. doi: 10.1038/ngeo159

Toké, N. A. (2011). Earthquake Geology, Hazard, Urban Form and Social Vulnerability Along the San Andreas Fault, 203. Doctoral dissertation, Arizona State University, Tempe, AZ.

Toké, N. A., Arrowsmith, J. R., Rymer, M. J., Landgraf, A., Haddad, D. E., Busch, M., et al. (2011) Late holocene slip rate of the san Andreas fault and its accommodation by creep and moderate-magnitude earthquakes at parkfield, California. Geology 39, 243-246. doi: 10.1130/G31498.1

Toké, N. A., Carlson, J. K., Barnum, E., Das-Toke, S., Dastrup, D. B., Ivie, H. A., et al. (2013). "Evidence for multiple surface ruptures with 0.3-1.5 meter slipper-event along structures between the Salt Lake City and Provo Segments of the Wasatch Fault," in Proceedings of the Geological Society of America Meeting Abstracts with Programs Paper No. 238-3, Denver, CO, October 29, 2013, Vol. 45, Denver, CO.

Toké, N. A., and Horns, D. M. (2017). Characterizing the Timing of Ruptures Crossing the Boundary between the Provo and Salt Lake City Segments of the Wasatch fault. U.S. Geological Survey, National Earthquake Hazards Reduction Program Final Technical Report, G16AP00104. 22. Available online 
at: https://earthquake.usgs.gov/cfusion/external_grants/reports/G16AP00104. pdf (accessed March 1, 2021).

Toké, N. A., Thomas, J., Bunds, M. P., Arnoff, M., Horns, D. M., and Carlson, J. K. (2017). "Inferences about fault segmentation from recent surface breaks along the Wasatch Front from Lidar, SfM, and outcrops from American Fork Canyon to Dimple Dell Regional Park," in Geology and Resources of the Wasatch: Back to Front, Vol. 46, W. R. Lund, S. H. Emerman, W. Wang, and A. Zanazzi, (Salt Lake City, UT: UGA Publication), 251-276.

Valentini, A., DuRoss, C. B., Field, E. H., Gold, R. D., Briggs, R. W., Visini, F., et al. (2019). Relaxing segmentation on the Wasatch fault zone: impact on seismic hazard. Bull. Seism. Soc. Am. 110, 83-109. doi: 10.1785/012019 0088

Verdecchia, A., Carena, S., Pace, B., and DuRoss, C. B. (2019). The effect of stress changes on time-dependent earthquake probabilities for the central Wasatch fault zone, Utah, USA. Geophys. J. Int. 219, 1065-1081. doi: 10.1093/gji/gg z336

Wang, H., Ran, Y., Chen, L., and Li, Y. (2017). Paleoearthquakeson the Anniinghe and Zemuhe fault along the southeastern margin of the Tibetan Plateau and implications for the fault rupture behavior at fault bends on strike-slip faults. Tectonophysics 721, 167-178. doi: 10.1016/j.tecto.2017.08.030

Weldon, R., Scharer, K., Fumal, T., and Biasi, G. (2004). Wrightwood and the earthquake cycle: what a long recurrence record tell us about how faults work. GSA Today 14, 4-10. doi: 10.1130/1052-51732004014<4:WATECW >2.0CO;2

Wells, D. L., and Coppersmith, K. J. (1994). New empirical relationships among magnitude, rupture length, rupture width, rupture area, and surface displacement. Bull. Seism. Soc. Am. 84, 974-1002.

Wesnousky, S. G. (2006). Predicting the endpoints of earthquake ruptures. Nature 444, 358-360. doi: 10.1038/nature05275

Wesnousky, S. G. (2008). Displacement and geometrical characteristics of earthquake surface ruptures-issues and implications for seismic-hazard analysis and the process of earthquake rupture. Bull. Seismol. Soc. Am. 98, 1609-1632. doi: 10.1785/0120070111

Western GeoLogic, (2004). Report, Geologic Hazards Evaluation, Three Falls Ranch, Alpine City, Utah, Unpublished Consultant Report, Downloaded from Utah Geological Survey GeoData Archive, 25. Available online at: https:// geodata.geology.utah.gov/pages/home.php (accessed March 1, 2021).

Wong, I., Lund, W., DuRoss, C., Thomas, P., Arabasz, W., Crone, A., et al. (2016). Earthquake Probabilities for the Wasatch Front Region in Utah, Idaho, and Wyoming, Utah Geological Survey Miscellaneous Publication 16-3. Salt Lake City, UT: Utah Geological Survey, 418.

Zielke, O., Arrowsmith, J. R., Grant-Ludwig, L. B., and Akciz, S. O. (2010). Slip in the 1857 and earlier large earthquakes along the Carrizo segment, San Andreas Fault. Science 327, 1119-1122. doi: 10.1126/science.118 2781

Zielke, O., Arrowsmith, J. R., Grant-Ludwig, L. B., and Akciz, S. O. (2012). High resolution topography-derived offset along the 1857 Fort Tejon earthquake rupture trace, San Andreas fault. Bull. Seis. Soc. Am. 102, 1135-1154. doi: 10.1785/0120110230

Conflict of Interest: The authors declare that the research was conducted in the absence of any commercial or financial relationships that could be construed as a potential conflict of interest.

Copyright (c) 2021 Toké, Phillips, Langevin, Kleber, DuRoss, Hiscock, McDonald, Wells, Carlson and Horns. This is an open-access article distributed under the terms of the Creative Commons Attribution License (CC BY). The use, distribution or reproduction in other forums is permitted, provided the original author(s) and the copyright owner(s) are credited and that the original publication in this journal is cited, in accordance with accepted academic practice. No use, distribution or reproduction is permitted which does not comply with these terms. 